\title{
PAPEL DO RECEPTOR NLRP12 NA MODULAÇÃO DA REABSORÇÃO ÓSSEA DURANTE A PROGRESSÃO DA LESÃO PERIAPICAL EXPERIMENTAL
}

Dissertação apresentada à Faculdade de Odontologia de Ribeirão Preto da Universidade de São Paulo, para a obtenção do Título de Mestre em Ciências.

Programa: Odontopediatria

Área de Concentração: Odontopediatria

Orientadora: Profa. Dra. Sandra Yasuyo Fukada Alves

Ribeirão Preto 
AUTORIZO A REPRODUÇÃO E DIVULGAÇ̃̃O TOTAL OU PARCIAL DESTE TRABALHO, POR QUALQUER MEIO CONVENCIONAL OU ELETRÔNICO, PARA FINS DE ESTUDO E PESQUISA, DESDE QUE CITADA A FONTE.

\section{FICHA CATALOGRÁFICA}

Taira, Thaise Mayumi

Papel do receptor NLRP12 na modulação da reabsorção óssea durante a progressão da lesão periapical experimental.

Taira, Thaise Mayumi, Ribeirão Preto, 2017.

107p.: il, $30 \mathrm{~cm}$.

Dissertação de Mestrado apresentada à Faculdade de Odontologia de Ribeirão Preto da Universidade de São Paulo. Área de concentração: Odontopediatria.

Orientadora: Fukada, Sandra Yasuyo

1. NLRP12, 2. lesão periapical 3. reabsorção óssea, 4. MMP-9, 5. osteoimunologia. 
FolHa de Aprovação

TAIRA, TM. Papel do receptor NLRP12 na modulação da reabsorção óssea durante a progressão da lesão periapical experimental

Dissertação apresentada à Faculdade de Odontologia de Ribeirão Preto da Universidade de São Paulo, para a obtenção do Título de Mestre em Ciências.

Área de Concentração: Odontopediatria

Aprovado em:

BANCA EXAMINADORA

Prof. Dr.

Instituição:

Julgamento: Assinatura:

Prof. Dr.

Instituição:

Julgamento: Assinatura:

Prof. Dr.

Instituição:

Julgamento: Assinatura: 



\section{Thaise Mayumi TaIRA}

Nascimento 31 de julho 1991, Tupã, SP

Filiação Lauro Taira

Alice Akiko Nacashima Taira

2010-2014 Graduação em Odontologia

Faculdade de Odontologia de Ribeirão Preto da Universidade de São Paulo -FORP/USP

2011-2012 Iniciação Científica - Bolsista RUSP

Faculdade de Odontologia de Ribeirão Preto da Universidade de São Paulo - FORP/USP

"Papel do receptor NOD2 na modulação da osteoclastogênese"

Orientadora: Profa. Dra. Sandra Yasuyo Fukada Alves

2012-2013 Iniciação Científica - Bolsista RUSP

Faculdade de Odontologia de Ribeirão Preto da Universidade de São Paulo - FORP/USP

"Papel do receptor NOD2 na atividade dos osteoclastos"

Orientadora: Profa. Dra. Sandra Yasuyo Fukada Alves

2015-2016 Aperfeiçoamento em Atendimento Odontológico a Pacientes Especiais.

Faculdade de Odontologia de Ribeirão Preto - FORP/USP

2015-2017 Mestrado em Ciências

Área de Concentração: Odontopediatria

Faculdade de Odontologia de Ribeirão Preto da Universidade de São Paulo- FORP/USP

Dissertação: "Papel do receptor NLRP12 na modulação da reabsorção óssea durante a progressão da lesão periapical experimental"

Orientadora: Profa. Dra. Sandra Yasuyo Fukada Alves 

"Talvez não tenha conseguido fazer o melhor, mas lutei para que o melhor fosse feito. Não sou o que deveria ser, mas Graças a Deus, não sou o que era antes".

Marthin Luther King 

Dedico este trabalho aos meus pais, Lauro Taira e Alice Akiko Nacashima Taira, que sempre me apoiaram em todas as minhas decisões, me mantendo firme e forte para seguir com os meus sonhos sempre com os pés no chão. Sou muito grata pela dedicação e amor, pelos esforços. Amo muito vocês!

Ao meu irmão, Thiago Satoru Taira, por toda amizade e conversas. Tento me espelhar em você, no seu esforço, dedicação e foco pelos seus objetivos. Te admiro muito.

Ao meu namorado, Reinaldo Mitsuo Sato Kumata, obrigada por todo carinho, paciência, companheirismo e por sempre me aconselhar nas minhas decisões. Você é muito especial para mim, te amo!

A todos das famílias Taira, Nacashima, e amigos, pela torcida a cada conquista, pelo apoio e sorrisos. 



\section{AGRADECIMENTO ESPECIAL}

Agradeço à minha orientadora Profa. Dra. Sandra Yasuyo Fukada Alves por toda a ajuda durante a execução deste trabalho, pela confiança depositada a mim e por toda a dedicação para que este fosse executado da melhor maneira possivel. Muito obrigada por todo o aprendizado, disponibilidade, atenção, compreensão e pela amizade. Admiro muito sua minuciosidade e competência. 



\section{AGRADECIMENTOS}

À Faculdade de Odontologia de Ribeirão Preto da Universidade de São Paulo, na pessoa da atual Diretora Profa. Dra. Léa Assed Bezerra da Silva e do Vice-diretor Prof. Dr. Arthur Belém Novaes Júnior e à Coordenação do Curso de Pós-Graduação em Odontopediatria da Faculdade de Odontologia de Ribeirão Preto da Universidade de São Paulo, na pessoa da coordenadora, Profa. Dra. Raquel Assed Bezerra Segato.

Aos professores do Departamento de Clínica Infantil da Faculdade de Odontologia de Ribeirão Preto da Universidade de São Paulo pelos valiosos ensinamentos durante minha formação acadêmica e científica e pela oportunidade de conviver com vocês.

Aos professores da Faculdade de Medicina de Ribeirão Preto da Universidade de São Paulo, Prof. Dr. Fernando de Queiroz Cunha, Prof. Dr. José Carlos Alves Filho e Prof. Dr. Thiago Mattar Cunha, pela cordialidade e pela cooperação durante a realização desta pesquisa.

Ao professor Dr. Dario Simões Zamboni da Faculdade de Medicina de Ribeirão Preto da Universidade de São Paulo pelo apoio ao projeto com os animais deficientes Nlrp12. 
Aos professores da banca e suplentes, por terem aceito o convite e pela atenção dispensada na leitura da dissertação.

Aos pós-graduandos em Odontopediatria da Faculdade de Odontologia de Ribeirão Preto da Universidade de São Paulo, principalmente à minha turma de mestrado pela convivência, trocas de experiências, por todo apoio e amizade.

Às técnicas Mayara Santos Gomes e Nilza Letícia Magalhães, por todo auxílio e ensinamento durante a realização dos experimentos laboratoriais.

Às minhas amigas de laboratório, Alessandra Parreira Menino, Cecília Costa do Carmo e Silva, Liseth Wilches Buitrago, por toda ajuda durante a execução laboratorial desse projeto e pela amizade.

Aos funcionários do Departamento de Clínica Infantil, da Clínica de Pacientes Especiais, da Seção de Pós-graduação, enfim, todos os funcionários da Faculdade de Odontologia de Ribeirão Preto da Universidade de São Paulo e aos funcionários da Faculdade de Farmácia e Medicina de Ribeirão Preto da Universidade de São Paulo pela disponibilidade, pela atenção e por toda a ajuda durante este período.

À Coordenação de Aperfeiçoamento de Pessoal de Nivel Superior (CAPES) pela bolsa concedida e à Fundação de Amparo à Pesquisa do Estado de São Paulo (FAPESP) pelo suporte financeiro para que esse projeto fosse executado. 
Por fim, agradeço a todos que de maneira direta ou indireta contribuíram para a concretização deste trabalho e, também, a todos que passaram de alguma forma por minha vida durante esse período. Muito obrigada! 

TAIRA, TM. Papel do receptor NLRP12 na modulação da reabsorção óssea durante a progressão da lesão periapical experimental. Ribeirão Preto, 2017. 107p. Dissertação (Mestrado)- Faculdade de Odontologia de Ribeirão Preto, Universidade de São Paulo.

\section{RESUMO}

O receptor NLRP12 é um receptor intracelular que está envolvido no reconhecimento de PAMPs e DAMPs durante uma infecção. Foi visto que durante a osteoclastogênese, há uma diminuição da transcrição de NLRP12, e que este receptor inibe a reabsorção óssea através da supressão da via alternativa de NF-кB, exercendo um papel protetor sobre o tecido ósseo. Além disso, foi observado que a deficiência de NLRP12 em monócitos sob o estímulo de RANKL levou a maior estabilização de NIK e maior translocação de RelB para o núcleo, aumentando a formação dos osteoclastos in vitro. Portanto, o objetivo deste estudo foi avaliar o papel de NLRP12 no desenvolvimento e progressão da lesão periapical induzida em camundongos. Para isso, foi induzida a lesão periapical dos primeiros molares inferiores dos camundongos fêmeas C57/BI6 (WT) e camundongos deficientes para o receptor NLRP12 (Nlrp12/-). Após 14 e 21 dias, as amostras de mandíbula foram submetidas às análises: determinação da área de lesão periapical em cortes histológicos; expressão gênica de marcadores osteoclastogênicos por qPCR; contagem de osteoclastos submetidos ao ensaio de histoenzimologia (TRAP); avaliação enzimática das MMPs por Zimografia. Os linfonodos cervicais foram submetidos à análise da expressão dos fatores de transcrição T-bet, RORyt, GATA-3 e Foxp-3 por qPCR. Aos 14 dias, na análise histomorfométrica os animais Nlrp12 apresentaram uma maior lesão periapical quando comparados aos animais WT, associado com o aumento da expressão de Trap, Catepsina K e MMP-9 em amostras de hemimandíbulas com lesão. Além disso, o número de células TRAP positivas foi significantemente maior em Nlrp12\%-- com lesão quando comparado com seu controle, enquanto no grupo WT com e sem lesão foram semelhantes. Assim como foi observado o maior aumento dos osteoclastos presentes no local da lesão dos animais Nlrp12 ${ }^{-/}$, estes também se mostraram com maior atividade gelatinolítica de MMP-9 e MMP-2 em relação ao seu controle, diferente dos animais WT que não apresentaram diferença entre os grupos controle e com lesão. Ainda nesse período, foi observado nas amostras de linfonodos cervicais que, no grupo Nlrp12 $2^{--}$houve uma tendência à maior expressão de RORyt, seguidos de menor expressão de T-bet quando comparados com o grupo WT. Aos 21 dias, os animais WT e Nlrp12\%apresentaram lesões periapicais de tamanhos semelhantes. Além disso, somente o grupo Nlrp12 $2^{--}$com lesão apresentou um aumento significativo da expressão de Trap em relação ao seu controle e a expressão de Catepsina $\mathrm{K}$ foi semelhante em ambos os grupos. Neste período houve um aumento na quantidade de células TRAP positivas em ambos os grupos com lesão quando comparados com seus respectivos controles, entretanto também não houve diferença entre os animais WT e NIrp12\%. A atividade de MMP-9 e MMP-2 foram semelhantes entre os animais WT e NIrp12 ${ }^{--}$e entre seus respectivos controles aos 21 dias. Nossos dados sugerem que a deficiência de NLRP12 levou a uma maior perda óssea aos 14 dias de lesão periapical e que isso ocorre via modulação da formação e atividade dos osteoclastos. Portanto, o NLRP12 inibe a osteoclastogênese e a atividade dos osteoclastos durante a fase inicial da lesão periapical, retardando o desenvolvimento da doença.

Palavras-chave: NLRP12, lesão periapical, reabsorção óssea, MMP-9, osteoimunologia. 

TAIRA, TM. Role of NLRP12 on bone resorption during the progression of a periapical lesion model. Ribeirão Preto, 2017. 107p. Masters dissertation- School of Dentistry of Ribeirão Preto, University of São Paulo.

\begin{abstract}
NLRP12 is an intracellular sensor that recongnizes PAMPS and DAMPs during infeccion. It was seen that NLRP12 transcription is down-regulated during osteoclastogenesis, and NLRP12 protect bone via suppression of alternative NF-KB-induced osteoclastogenesis. It has been shown that NLRP12 deficiency in monocytes under RANKL stimuli exhibited more stabilization of NIK and nuclear translocation of RelB, increasing osteoclasts formation in vitro. Therefore, the aim of this study was to evaluate the role of NLRP12 in the development and progression of experimentally induced periapical lesions in mice. Periapical lesions were induced in first molars of WT and NLRP12 knockout (KO) mice. Samples were collected at 14 and 21 days of the lesion for the analyses. Jaw samples with lesion and control area were subjected to periapical lesions area determination by histological sections; osteoclastogenic markers expression by q-PCR; count of osteoclasts submitted to the enzyme assay for TRAP; evaluation of MMPs activity by Zymography. The expression of T cells markers' transcription factors was evaluated in lymph nodes by q-PCR. Fourteen days after periapical lesion induction, histological analysis revealed that NLRP12KO mice exhibited higher area of periapical lesion compared to WT group, which was associated with upregulated mRNA expression of Trap, Cathepsin K and MMP-9 in the jaw samples. Moreover, the number of multinuclear TRAP-stained cells was significantly higher in the NLRP12KO with lesion group when compared to it control, whereas in the WT the number between the lesion and control groups were similar. Still, NLRP12KO showed higher MMP-9 and -2 gelatinolytic activity than it control, unlike WT mice that showed no difference between control and lesion group. In this period, NLRP12KO mice lymph nodes showed more RORyt expression than WT mice and less T-bet expression. At 21 days, WT and NLRP12KO presented periapical lesions of similar sizes. In addition, NLRP12KO group with lesion showed a significant increase in Trap expression when compared with their control, but the increase in Trap e Cathepsin $\mathrm{K}$ was similar in both groups. Additionally, there was an increase of multinuclear TRAP-stained cells in both lesion groups when compared with their respective controls; however, there was also no difference between WT and NLRP12KO mice. MMP-9 and -2 activity was similar between WT and NLRP12KO and with their respective controls at 21 days. Our results suggest that NLRP12 deficiency led to increased bone loss at 14 days of periapical lesion and it occurs due to increased osteoclasts formation and activity. Therefore, NLRP12 inhibits osteoclastogenesis and osteoclasts activity during the early stages of periapical lesion, slowing the development of the disease.
\end{abstract}

Keys-word: NLRP12, periapical lesion, bone resorption, MMP-9, osteoimmunology. 



\section{LISTA DE FIGURAS}

Figura 1. Determinação da expressão gênica de Trap e Catepsina $\mathrm{K}$ em osteoclastos.

Figura 2. Fotos representativas da cultura de osteoclastos.

Figura 3. Quantificação do número de osteoclastos in vitro.

Figura 4. Determinação da área dos osteoclastos in vitro.

Figura 5. Fotos representativas de cortes corados com HE aos 14 dias de lesão.

Figura 6. Determinação do tamanho da lesão periapical por histomorfometria após 14 dias de lesão.

Figura 7. Fotos representativas de cortes corados com HE aos 21 dias de lesão.

Figura 8. Determinação da área da lesão periapical aos 21 dias de lesão por histomorfometria

Figura 9. Determinação da expressão gênica de marcadores de células $T$ aos 14 dias.

Figura 10. Avaliação da expressão gênica dos fatores de transcrição de células $T$ aos 21 dias de lesão

Figura 11. Determinação da expressão gênica de marcadores de osteoclastos aos 14 dias de lesão

Figura 12. Avaliação dos marcadores de osteoclastos por qPCR aos 21 dias de lesão.

Figura 13. Fotos representativas de cortes corados com TRAP aos 14 dias de lesão...

Figura 14. Após 14 dias de lesão, quantificação das células marcadas com TRAP.

Figura 15. Fotos representativas de cortes corados com TRAP aos 21 dias de lesão.

Figura 16. Quantificação das células TRAP positivas com 21 de lesão.

Figura 17. Avaliação da atividade proteolítica das metaloproteinases.

Figura 18 Avaliação da atividade enzimática de MMP-9 e MMP2. 



\section{Lista de Abreviaturas, Siglas e Símbolos}

a: alfa

a-MEM: Minimum Essencial Medium Eagle- Alpha Modification

ANOVA: análise de variância

Atp6v0d2: $d 2$ isoform of vacuolar ATPase $V_{0}$ domain

B: beta

C: celsius

$\mathrm{CaCl}_{2}$ : cloreto de cálcio

cDNA: ácido desoxirribonucleico complementar (complementar deoxyribonucleic acid)

c-fms: macrophage colony stimulating factor receptor

c-fos: fosfolipase $\mathrm{C}$

CSF1R: colony stimulating factor receptor

CT: cycle threshold

CTR: calcitonin receptor

Ctsk: catepsina $\mathrm{K}$

DAMPs: padróes moleculares associados ao dano

DC-STAMP: dendritic cell-specific transmembrane protein

$\Delta:$ delta

EDTA: Ethylenediamine Tetracetic Acid

FOXP-3: forkhead/winged helix transcription factor $\mathrm{p} 3$

GATA-3: Guanine-Adenine-Thymine-Adenine - Fator de transcrição com capacidade se ligar à sequência de DNA GATA

g: grama (s)

$\circ$ : graus

HE: hematoxilina e eosina

IFN-y: interferon-gamma

IkBs: nuclear factor of kappa light polypeptide gene enhancer in B-cells inhibitor

IKKa: inhibitor of $\mathrm{KB}$ kinase alpha

IL- : interleucina-

kDA: kilodalton

M-CSF: Fator estimulador de colônia de macrófagos

MITF: fator de transcrição associado a microftalmia

MMPs: metaloproteinases da matriz

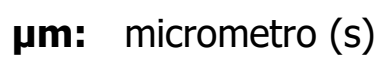

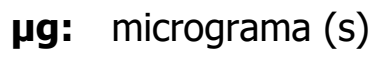

$\boldsymbol{\mu L}$ microlitro (s) 
mA: miliampere

mg: miligrama (s)

min: minuto (s)

mL: mililitro (s)

$\mathbf{m m}^{2}$ : milimetro(s) quadrado (s)

NFAT: NF of activated T-cell

NF-kB: fator de transcrição nuclear kappa B (nuclear factor kappa B)

NIK: NF-kB-inducing kinase

NLRs: receptores tipo NOD (Nod-like receptors)

NLRP12: Nod-like Receptor Family Pyrin Domain Containing 12

OPG: osteoprotegerina

OSCAR: osteoclast-associates immunoglobulin-like receptor

\%: por cento

PAMPs: padrões moleculares associados ao patógeno

PBS: tampão fosfato salina

PRRs: receptores de reconhecimento de padrões moleculares

pH: potencial hidrogeniônico

qPCR: reação em cadeia da polimerase quantitativa (quantitative polymerase chain reaction)

RANK: receptor ativador de NF-KB

RANKL: ligante do receptor ativador de NF-KB

RelB: Reticuloendotheliosis Viral Oncogene Homolog B

RIPA: radio immunoprecipitation assay

RNA: ácido ribonucleico (ribonucleic acid)

RNAm: ácido ribonucleico mensageiro

RORYt: retinoic acid-related orphan receptor gamma

rpm: rotações por minuto

s: segundo (s)

Tbet: T-box expressed in T cells

TGF- $\beta$ : Fator de crescimento transformador beta (transforming growth factor beta)

Th-: Thelper

TLRs: receptores tipo Toll (Toll-like receptors)

TNF-a: Fator-alfa de necrose tumoral (tumor necrosis factor)

TRAF6: fator 6 associado ao receptor de TNF (TNF receptor-associated factor 6 )

TRAP: fosfatase ácida resistente ao tartarato (tartrate-resistant acid phosphatase)

Treg: Treguladoras

WT: wild-type

V-ATPase: vacuolar-type $\mathrm{H}^{+}$-ATPase

V: volts 


\section{SUMÁRIO}

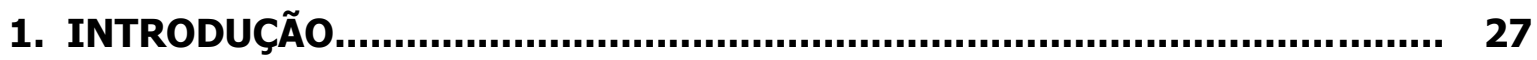

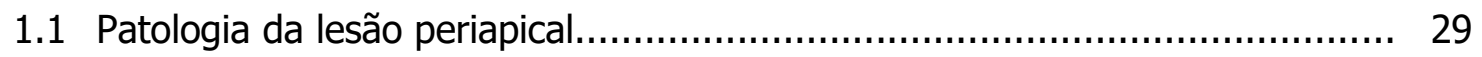

1.2 Receptor NLRP12 e Osteoimunologia................................................ 30

1.3 Tecido ósseo e o processo da reabsorção óssea.......................................... 33

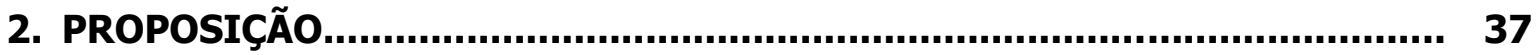

3. MATERIAL E MÉTODOS.................................................................... 41

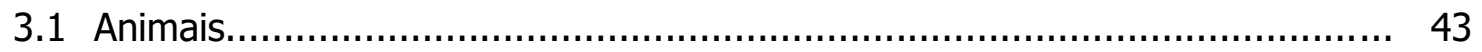

3.2 Cultura de osteoclastos murinos.......................................................... 43

3.3 Determinação do número de osteoclastos pela reação de TRAP.................... 44

3.4 Indução da lesão periapical................................................................. 44

3.5 Análise histomorfométrica da extensão da reabsorção óssea periapical e determinação do número de osteoclastos .............................................. 45

3.6 Avaliação da expressão gênica de marcadores de osteoclastos e de genes relacionados ao sistema imune......................................................... 46

3.7 Avaliação da atividade enzimática das metaloproteinases da matriz por

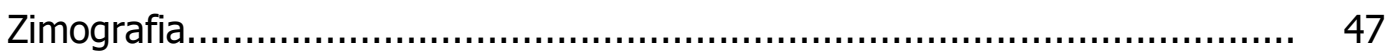

3.8 Análise estatística....................................................................... 48

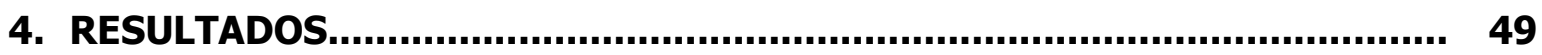

4.1 Avaliação do modelo in vitro........................................................ 51

4.1.1 Expressão gênica de marcadores de osteoclastos em cultura de células osteoclásticas após 72 horas de cultivo............................................ 51

4.1.2 Quantificação do número e tamanho dos osteoclastos após 96 horas de

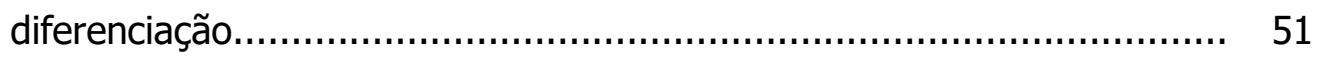

4.2 Avaliação do modelo in vivo........................................................... 56

4.2.1 Participação do receptor NLRP12 na modulação da reabsorção óssea durante a periodontite apical induzida........................................... 56

4.2.2 Expressão gênica de marcadores de células $T$ em linfonodos

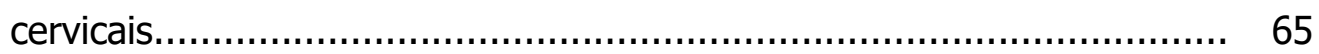

4.2.3 Expressão gênica de marcadores de osteoclastos em hemi-mandíbulas após a indução da lesão periapical..................................................... 68

4.2.4 Determinação do número de osteoclastos pelo ensaio enzimático de TRAP. 
4.2.5 Avaliação da atividade proteolítica das enzimas responsáveis pela degradação da matriz extracelular durante a reabsorção óssea............. 79

5. DISCUSSÃO..................................................................................... 83

6. CONCLUSÃO............................................................................................ 91

REFERÊNCIAS........................................................................................ 95

ANEXO.................................................................................................... $\quad 105$ 
1. Introdução 



\section{INTRODUÇÃO}

\subsection{Patologia da lesão periapical}

Lesão periapical é uma doença de origem inflamatória causada por qualquer agressão ao tecido pulpar, e que resulta na destruição dos tecidos ao redor do ápice radicular, como o ligamento periodontal, cemento e osso alveolar. Essa lesão inflamatória pode ser tanto de caráter agudo quanto crônico, dependendo da intensidade e duração do agente causador. Há lesões periapicais causadas por danos assépticos como trauma dental e irritação por materiais endodônticos ou químicos, porém, evidências clínicas indicam que na maioria dos casos, as lesões periapicais são induzidas por bactérias (Márton e Kiss, 2000).

Agressões químicas, físicas e bacterianas podem levar a um quadro de inflamação e quando essa inflamação se torna maior que a capacidade de defesa da polpa, ocorre a necrose desse tecido. O tecido pulpar em decomposição e desintegração irá favorecer a invasão microbiana (Silva et al., 2015). Consequentemente, esse processo levará à contaminação dos canais radiculares em grande parte pela microbiota bucal, e o efluxo contínuo de bactérias e seus subprodutos pelo forame apical irão induzir a migração, a ativação e a interação coordenada das células do sistema imunológico na região periapical. No entanto, os mecanismos de defesa do hospedeiro ativados com o objetivo de conter os microorganismos, não ficam restritos à destruição bacteriana, mas também podem induzir a destruição do tecido adjacente e finalmente levar a reabsorção óssea apical (Márton e Kiss, 2000). Portanto, se estas lesões não forem tratadas e se ainda houver a incapacidade de defesa do hospedeiro em conter a infecção, a consequência disto será a destruição progressiva do tecido ósseo bem como de todas as estruturas circundantes ao ápice dental (Gazivoda et al., 2009).

O desenvolvimento e a progressão da lesão periapical é caracterizado principalmente pela redução das bactérias Gram-positivas aeróbicas, seguido do aumento de bactérias Gram-negativas anaeróbicas, que invadem o sistema de canais radiculares e os tecidos periapicais (Leonardo et al., 2002; Rocha et al., 2008). Desta forma, as bactérias anaeróbias liberam várias toxinas como o lipopolissacarídeo (LPS), ácido lipoteicóico (LTA) e alguns metabólitos nocivos que induzem uma 
resposta inflamatória da polpa e do tecido periapical, promovendo a ativação do sistema imunológico (Metzger, 2000; Rocha et al., 2007; Jang et al., 2015).

Durante 0 desenvolvimento da lesão periapical vários mediadores inflamatórios são produzidos como a interleucina (IL-) 1, fator de necrose tumoral-a (TNF-a), IL-6 (Akira et al., 2006), sendo que a sinalização mediada por estas citocinas, além de outras quimiocinas se fazem importante para maturação e atividade dos osteoclastos no local (Paula-Silva et al., 2016). Portanto, o curso da doença é influenciado pela virulência da microbiota bucal presente no canal radicular e à capacidade do sistema imune em conter o processo infeccioso (Zehnder e Belibasakis, 2015).

\subsection{Receptor NLRP12 e Osteoimunologia}

O sistema imune inato constitui a primeira linha de defesa da polpa, o qual é ativado pelo reconhecimento dos patógenos pelos receptores de reconhecimento padrão (PRRs).

Os PRRs são uma classe de receptores que reconhecem padrões moleculares associados a patógenos (PAMPs), e sua ativação tem um papel fundamental na geração da resposta imune inata, até o momento em que a imunidade adaptativa é ativada. Dentre estes receptores destacam-se os receptores Toll-like (TLRs) e receptores NOD-like (NLRs) (Jang et al., 2015), tendo estes últimos se mostrado importante em vários aspectos das respostas imune e inflamatória (Carneiro e Travassos, 2013).

Receptores NLRs são PRRs citoplasmáticos que, semelhantemente aos receptores TLRs, possuem um papel importante na resposta imune inata por reconhecerem PAMPs e padrões moleculares associados ao dano (DAMPs), sendo divididos em quatro subfamílias a depender de seu domínio N-terminal: NLRA, NLRB, NLRC, e NLRP (Kim et al., 2016). A detecção de PAMPs e DAMPs por certos NLRs pode resultar na formação de um complexo multiproteico denominado inflamassoma, que resulta na auto ativação de caspase-1 seguido da secreção de potentes citocinas próinflamatórias, a IL-1 $1 \beta$ e a IL-18 (Barton, 2008). Sendo assim, os membros dos NLRs tem sido, cada vez mais, associados com a regulação da imunidade inata e adaptativa, inflamação e auto-imunidade em diferentes aspectos, sendo emergido 
como um dos fatores que mais contribuem para as diversas doenças humanas (Allen et al., 2012). Embora a maioria dos NLRs seja caracterizado por exercer um papel pró-inflamatório, estudos recentes identificaram que alguns NLRs possuem a habilidade de atenuar a inflamação, pelo controle da caspase-1 ou por supressão da via de NF-kB (Williams et al., 2003; Conti et al., 2005; Lich et al., 2007; Barton, 2008; Cui et a., 2010; Allen et al., 2011; Schneider et al., 2012).

O NLRP12 (formalmente conhecido como MONARCH-1 ou PYPAF7), um membro NLR, é expresso em células do sistema imune, de modo expressivo em células da linhagem monocítica (Allen et al., 2012; Zaki et al., 2011; Williams et al., 2005; Arthur et al., 2010), porém ainda há muita controvérsia sobre o seu papel durante uma infecção. Trabalhos demonstraram que o NLRP12 suprime a produção de citocinas e quimiocinas pró-inflamatórias pela supressão da via alternativa de NF-kB (Zaki et al., 2011; Allen et al., 2012). Além disso, Vladimer et al. (2012) mostrou que o inflamassoma NLRP12 controlou a produção de IL-1 $1 \beta$ e IL-18 após infecção com $Y$. petis, demonstrando que NLRP12 exerce um papel protetor a esta infecção.

Assim como NLPR12 suprime a via alternativa de NF-kB, a deficiência de NLRP12 potencializou a formação de osteoclastos in vitro, ao promover a estabilização de NIK e aumentar a translocação de RelB para o núcleo, podendo alterar a homeostase óssea a favor do processo de reabsorção óssea (Krauss et al., 2015). Estes autores mostraram que este receptor também desempenhou um papel importante dentro do processo de reabsorção óssea uma vez que a deficiência de NLRP12 em camundongos levou a uma maior perda óssea em modelo de calvária induzida por RANKL, entretanto o papel do receptor NLRP12 no desenvolvimento e progressão da lesão periapical permanece desconhecido.

Nos últimos anos tem se buscado entender as diversas funções de moléculas expressas tanto em células do sistema imune quanto do tecido ósseo, sendo que várias moléculas estudadas no sistema imune participam de funções essenciais no tecido ósseo (Guerrini \& Takayanagi 2014). A ciência que avalia essas interações e mecanismos compartilhados entre os sistemas esquelético e imunológico é denominado de osteoimunologia (Takayanagi, 2012). 
Portanto, compreender os mecanismos envolvidos na resposta imune pode muitas vezes nos ajudar a compreender o que ocorre no metabolismo ósseo, pois estas são unidades que se correlacionam e mantêm um padrão de resposta interdependente.

É descrito na literatura que as doenças inflamatórias têm potencial para alterar o metabolismo ósseo, e as citocinas inflamatórias como IL-1a (Gowen et al., 1983), TNF-a (Stashenko et al., 1994), IL-17 (Kotake et al., 1999, Sato et al., 2006) desempenham papel crucial no controle da reabsorção óssea. Além disso, os osteoclastos estão intimamente relacionados às células do sistema imune uma vez que se originam da linhagem de células monocíticas, que por sua vez se diferenciam em resposta ao RANKL, o qual é produzido por linfócitos promovendo a regulação da linfopoiese. Ainda, os osteoclastos expressam co-receptores típicos de células do sistema imune que são indispensáveis para a sua própria diferenciação (Del Fattore \& Teti, 2012).

Embora os osteoclastos e osteoblastos sejam os maiores reguladores do metabolismo ósseo, e sejam regulados por um microambiente local, a homeostase óssea é intensamente influenciada por componentes do sistema imune. Um exemplo é o processo de reabsorção óssea em condições inflamatórias desencadeada pela ação direta ou indireta de células T sobre os osteoclastos (Rho et al., 2004).

A interação entre o sistema imune e o metabolismo ósseo tem sido demonstrado em várias doenças, mostrando que a ativação do sistema imune pode levar a destruição do tecido ósseo (Fukada et al., 2009). Durante uma infecção bacteriana nos tecidos periapicais dentais, as células imunocompetentes dirigem e sedimentamse em áreas periapicais na tentativa de prevenir a disseminação de microbiota infecciosa. Entre essas células, os linfócitos $T$, também conhecidos como células $T$, são os mais prevalentes no infiltrado inflamatório periapical (Yu et al., 1987). Como RANKL é expresso em células $T$ ativas, estas devem participar do processo de diferenciação dos osteoclastos (Kong et al., 1999, Horwood et al., 1999). Todavia, as células T também secretam o IFN-y (Interferon-gama), que contrabalanceia o efeito de RANKL, por isso os efeitos das células $T$ sobre a osteoclastogênese devem ser dependentes do equilíbrio desses fatores (Sato et al., 2006). Dentre as células T sabe-se que em sítios infecciosos, como em lesões no periápice, há dois padrões de resposta que medeiam a proteção do hospedeiro, as células Th1 e Th2 (Jankovic et 
al., 2001), as quais são identificadas por expressar respectivamente T-bet e GATA-3 (Szabo SJ et al., 2000). Enquanto as respostas Th1/Th2 são induzidas por citocinas, seus padrões de respostas frente a um processo infeccioso são regulados por uma família heterogênea de células, conhecidas como células T reguladoras (Treg), tendo como seu principal regulador o fator de transcrição Foxp-3. Além disso, foi demonstrado que as células Treg podem regular criticamente o desequilíbrio entre a imunidade e a atividade dos osteoclastos em lesões periapicais (Fukada et al., 2009).

Um outro subtipo das células $T$, as Th17, por sua vez reguladas pelo fator de transcrição RORyt e conhecido por liberar a citocina IL-17, também tem sido avaliado na evolução das lesões periapicais (Marcal et al., 2010, Henriques et al., 2011). Sato et al. (2006) concluiu que as células Th17 podem ser chamadas de subconjunto Th osteoclastogênico, não só porque as células Th17 tem efeitos positivos na osteoclastogênese in vitro, mas também porque inclinam o equilíbrio dos microambientes em favor da diferenciação osteoclástica. Vale ressaltar que as células Th17 não induzem a osteoclastogênese na ausência de osteoblastos, sugerindo fortemente que o RANKL expresso em osteoblastos tenha efeitos mais potentes do que o expresso em células T (Sato et al., 2006). Como visto anteriormente, a modulação óssea pode ser regulada por diversos fatores frente a uma agressão, inclusive pela participação direta ou indireta de células $T$.

\subsection{Tecido ósseo e o processo da reabsorção óssea}

O tecido esquelético é constante e dinamicamente renovado em condições homeostáticas, de maneira a manter suas propriedades mecânicas (Guerrini \& Takayanagi, 2014). O equilíbrio entre a formação e reabsorção óssea é essencial para a homeostase esquelética, uma vez que o desequilíbrio é observado em patologias ósseas como na osteoporose (Novack et al., 2008, Manolagas 2000). As ações dos osteoblastos e osteoclastos são vitais para o desenvolvimento e remodelação óssea (Tanaka et al., 2013). A reabsorção óssea é uma atividade celular fundamental na modelagem do esqueleto, onde os osteoclastos desempenham um papel crucial (Feng et al., 2014). Os osteoblastos são células de origem mesenquimal cuja principal função é sintetizar componentes orgânicos da matriz óssea (colágeno tipo I, proteoglicanas e glicoproteínas), participando ativamente do processo de 
mineralização (Aubin, 2001). Por outro lado, os osteoclastos são células móveis e multinucleadas provenientes da linhagem mielóide da medula óssea responsáveis pelo processo de reabsorção óssea. A formação dos osteoclastos, denominado osteoclastogênese, envolve a diferenciação das células hematopoiéticas mielóides para pré-osteoclastos e, finalmente para osteoclastos maduros, os quais apresentam uma alta capacidade reabsorção óssea (Sims \& Gooi, 2008).

A identificação do sistema RANK/RANKL/OPG como 0 mediador da osteoclastogênese representou um grande avanço na biologia óssea (Khosla, 2001). É sabido que a expressão de RANKL pelos osteoblastos coordena a remodelação óssea por estimular o processo de diferenciação dos osteoclastos e ativação dos mesmos. Por outro lado, a OPG, também produzida por osteoblastos, bloqueia a ligação de RANKL em seu receptor celular RANK. Assim sendo, a superexpressão de OPG bloqueia a formação dos osteoclastos, enquanto que sua deleção causa um aumento do processo de reabsorção óssea, o que nos leva a compreender que o sistema RANKL/OPG é o sistema coordenador da reabsorção óssea por modificar o estado de ativação do receptor RANK nos osteoclastos (Boyle et al., 2003).

Duas citocinas atuam no processo de osteoclastogênese: o fator estimulador de colônias de macrófagos (M-CSF) e o ligante do receptor ativador de NF-KB (RANKL). A ação destas citocinas em seus receptores c-fms (CSF1R/MCSFR) e RANK, respectivamente, representam um papel crucial na osteoclastogênese.

O M-CSF é um fator de crescimento hematopoiético que promove não só a proliferação e sobrevida das células progenitoras, como também induz a expressão do receptor ativador de NF-kB (RANK) (Krauss et al., 2015).

O RANKL é uma citocina que pertence a superfamília do TNF e se liga no receptor RANK, o qual é expresso em monócitos, macrófagos e em pré-osteoclastos (Lacey et al., 1998; Nakagawa et al., 1998). A ativação do RANK pelo seu ligante promove o recrutamento da molécula adaptadora TRAF- 6 (fator 6 associado ao receptor de TNF), a qual leva a ativação de várias vias de sinalização intracelular, incluindo as vias clássica e alternativa do NF-kB, c-Fos, fosfolipase $\mathrm{C}$, fator de transcrição associado a microftalmia (MITF) e fator nuclear de células T ativadas c1 (NFATc1), as quais são importantes para os diferentes estágios de diferenciação dos osteoclastos (Luchin et al., 2001; Asagiri, 2007). 
Os mecanismos pelos quais estes fatores de transcrição apresentam um papel essencial para a osteoclastogênese envolve não só a regulação de inúmeros genes relacionados a diferenciação e fusão célular como calcitonin receptor (CTR), osteoclast-associated receptor (OSCAR), dendritic cell-specific transmembrane protein (DC-STAMP) e d2 isoform of vacuolar ATPase Vo domain (Atp6v0d2), bem como genes relacionados à ativação dos osteoclastos como fosfatase ácida resistente ao tartarato (TRAP) e catepsina K (Ctsk) (Yavropoulou \& Yovos, 2008). A importância da via NF-kB no controle da osteoclastogênese e massa óssea está bem estabelecido na literatura. Na via clássica do NF-kB, a ativação de RANK leva a degradação de IkBs associados a NF-kB, sendo então esta via ativada e permitindo a translocação de vários complexos NF-kB para o núcleo. Já a via alternativa de NF-kB, regulada pela ativação de NLRP12, utiliza diferentes moléculas adaptadoras e kinases para regular a diferenciação osteoclástica. Dentre as kinases, foi observado que a estabilização e acúmulo intracelular de NIK leva a ativação de IKKa. Esta quinase tem como alvo a p100, que leva a seu processamento para p52 promovendo subsequente translocação do heterodímero p52/RelB NF-kB para o núcleo (Krauss et al., 2015). Vaira et al. (2008) demonstrou que a ablação de NIK ou RelB na via alternativa de NF-kB não alterou a função dos osteoclastos em condições normais in vitro, por outro lado foi observado uma redução significativa da reabsorção óssea em condições inflamatórias. Além disso, camundongos deficientes para NIK demonstraram resistência a reabsorção óssea e a osteoclastogênese, em modelo de calvária induzida por LPS (Soysa et al., 2011). Portanto, a ativação desta via alternativa de NF-kB, via NIK ou RelB, tem demonstrado ser de grande importância na diferenciação dos osteoclastos e na reabsorção em condições patológicas.

A reabsorção óssea exige uma série de modificações por parte dos osteoclastos maduros que compreendem em um intenso remodelamento citoesquelético, polarização da membrana plasmática, redistribuição de transportadores e organelas e um intenso tráfego endossomal. A reabsorção óssea inicia com a formação da zona de selamento que é caracterizada pela adesão celular na superfície óssea mineralizada, por meio de integrina tipo alfa v beta 3 (integrina av $\beta 3$ ) e formação de lacunas de reabsorção, para onde são secretados ácido e enzimas proteolíticas. A manutenção do $\mathrm{pH}$ ácido por $\mathrm{H}^{+}$ATPase vacuolares nestas lacunas são importantes 
para amplificação da atividade das enzimas proteolíticas secretadas de vesículas, como o TRAP, catepsina $\mathrm{K}$ e metaloproteinase da matriz 9 (MMP-9), permitindo assim a desmineralização e degradação de colágeno (Kalervo-Vaananen et al., 2008). A catepsina $\mathrm{K}$ é responsável pela degradação de colágeno tipo I, sendo reconhecida como a principal enzima de degradação óssea (Wilson et al., 2009). Já as metaloproteinases da matriz (MMPs) são enzimas principalmente responsáveis pela degradação de macromoléculas da matriz extracelular (Sousa et al., 2014) e são elas as primeiras enzimas a darem início ao processo de reabsorção óssea. Vários membros desta família estão envolvidas na patogênese das lesões periapicais, dentre elas a MMP-2 e MMP-9 classificadas como gelatinases, as quais estão relacionadas com a degradação da matriz extracelular principalmente nos estágios ativos do desenvolvimento da lesão periapical (Corotti et al., 2009).

Portanto, sabendo que o NLRP12 tem participação na regulação da resposta inflamatória e na via reguladora da osteoclastogênese, nossa hipótese é que este receptor possa modular o desenvolvimento e a progressão das lesões periapicais. 
2. Proposição 



\section{PROPOSIÇÃO}

O objetivo do presente estudo foi avaliar o papel do receptor NLRP12 na modulação do processo de reabsorção óssea em modelo de periodontite apical induzida em camundongos deficientes para os receptor NLRP12 (NIrp12-/) comparados aos animais wild-type (WT) por meio de:

2.1 análise histológica da extensão da lesão periapical em cortes submetidos à coração com hematoxilina eosina (HE);

2.2 avaliação da expressão gênica de genes relacionados ao sistema imune nos linfonodos cervicais;

2.3 avaliação da expressão gênica de marcadores osteoclastogênicos e da atividade dos osteoclastos nas hemi-mandíbulas: Trap (Acp5), V-ATPase (Atp6v0d2), Catepsina K (Ctsk) e Metaloproteinase da matriz 9 (MMP-9), por meio da técnica de qPCR;

2.4 quantificação do número de células gigantes multinucleadas (osteoclastos) na região apical por meio da histoenzimologia em cortes submetidos à reação da fosfatase ácida resistente ao tartarato (TRAP);

2.5 avaliação da atividade gelatinolítica da MMP-9 e MMP-2 em amostras de hemi-mandíbulas por meio da técnica de Zimografia. 

3. Material e Métodos 



\section{MATERIAL E MÉTODOS}

O presente estudo foi submetido à apreciação de acordo com os Princípios Éticos na Experimentação Animal junto ao Comitê de Ética no Uso de Animais da Faculdade de Ciências Farmacêuticas de Ribeirão Preto da Universidade de São Paulo (Processo $n^{\circ}$ 16.5.162.60.9, ver ANEXO).

\subsection{Animais}

Para a realização deste trabalho foram utilizados camundongos isogênicos fêmeas da linhagem C57/BL6 (WT), de 6-8 semanas de idade, adquiridos do Biotério Central do Campus de Ribeirão Preto da Universidade de São Paulo, e camundongos fêmeas knockout para o receptor NLRP12 (Nlrp12-/), de 6-8 semanas de idade, gentilmente cedidos pelo Prof. Dr. Dario Simões Zamboni do Departamento de Biologia Celular e Molecular e Bioagentes Patogênicos da Faculdade de Medicina de Ribeirão Preto da Universidade de São Paulo. Os animais foram mantidos em caixas pequenas ( 5 animais por caixa) no biotério da Faculdade de Ciências Farmacêuticas de Ribeirão Preto I e receberam os cuidados de rotina. Os mini-isoladores dos animais foram forrados com maravalha e ficaram organizados em estantes ventiladas com sistemas independentes de insuflamento e exaustão de ar. Os animais foram alimentados com ração à vontade e água filtrada ad libitum.

\subsection{Cultura de osteoclastos murinos}

A diferenciação de osteoclastos murinos foi realizada a partir de cultura primária utilizando células da medula óssea. Para isso, fêmur e tíbia de camundongos WT e NIrp12\%- foram assepticamente removidos e as medulas ósseas extraídas e mantidas por 3 dias em meio de cultura a-MEM (GIBCO, Invitrogen, Carlsbad, CA) suplementada com $10 \%$ soro fetal bovino, 100 unidades $/ \mathrm{mL}$ de penicilina e 100 $\mathrm{mg} / \mathrm{mL}$ de estreptomicina (ThermoScientific, Carlsbad, CA, USA) na presença de 30 $\mathrm{ng} / \mathrm{mL}$ de M-CSF (R\&D Systems). As células não aderidas foram removidas e eliminadas, e as células aderidas (pré-osteoclastos) foram cultivadas na presença de $30 \mathrm{ng} / \mathrm{mL}$ de M-CSF e $10 \mathrm{ng} / \mathrm{mL}$ de RANKL (R\&D Systems) por diferentes tempos, de 
acordo com o protocolo de estudo. Foram utilizadas as seguintes metodologias para avaliar a diferenciação dos osteoclastos:

- Para o ensaio de TRAP, 20.000 pré-osteoclastos foram plaqueados em placa de 96 poços e cultivadas na presença de M-CSF e de RANKL por 4 dias. Em seguida foi realizado o ensaio histoquímico de coloração de células multinucleadas sensíveis ao TRAP.

- Para o ensaio de qPCR, 200.000 pré-osteoclastos foram plaqueados em placa de 24 poços na presença de M-CSF e de RANKL por 3 dias. A expressão dos genes marcadores de osteoclastos como TRAP e Catepsina $\mathrm{K}$, foi avaliada por PCR em tempo real.

\subsection{Determinação do número de osteoclastos pela reação de TRAP}

A detecção de osteoclastos foi realizada pela reação de fosfatases ácidas resistentes ao tartarato - TRAP (KIT SIGMA 387-A). As células foram primeiramente fixadas com tampão de citrato por 20 minutos, lavadas com PBS e incubadas a $37^{\circ} \mathrm{C}$ na solução corante contendo tartaratos por 40 minutos, ao abrigo da luz, de acordo com as instruções do fabricante. Em seguida, os osteoclastos (células coradas e contendo 3 ou mais núcleos) foram fotografados e quantificados quanto ao número e tamanho das células utilizando o programa de imagens (ImageJ software).

\subsection{Indução da lesão periapical}

Os animais WT e Nlrp12\%- foram submetidos ao protocolo clássico de indução de lesão periapical. (De Rossi et al., 2008; Da Silva et al., 2012). Para tanto, os animais foram anestesiados via intraperitoneal com cloridrato de Cetamina (Ketamina 10\%, Agener União Química Farmacêutcia Nacional S/A. Embu-Guaçu, SP) na dosagem de $0,1 \mathrm{~mL} / \mathrm{Kg}$ de peso, e cloridrato de Xilazina (Anasedan ${ }^{\circledR} 2 \%$, Ceva Santé Animale S/A. Paulínea, SP), também na dosagem de $0,1 \mathrm{~mL} / \mathrm{Kg}$ de peso. Após anestesia, os animais foram posicionados em mesa cirúrgica especialmente desenvolvida para realização de procedimentos odontológicos em camundongos de maneira a garantir o acesso e a visualização dos molares inferiores. A indução da lesão periapical foi realizada no primeiro molar inferior direito com broca esférica de aço inoxidável $1 / 4$ acoplada à caneta de baixa rotação e contra-ângulo. $O$ tamanho da 
exposição foi padronizado de acordo com o diâmetro da broca e, os canais foram deixados expostos ao meio ambiente bucal. o lado esquerdo, ou seja, o lado sem exposição pulpar, constituiu o grupo controle. Após o período de 14 ou 21 dias, os animais foram aleatoriamente submetidos à eutanásia com superdose anestésica.

\subsection{Análise histomorfométrica da extensão da reabsorção óssea periapical e determinação do número de osteoclastos}

Após eutanásia, as mandíbulas foram removidas dos animais e dissecadas com instrumental esterilizado. As peças foram então imersas em formol tamponado a $10 \%$ por 24 horas à temperatura ambiente. A seguir, as hemi-mandíbulas foram lavadas em água corrente por 8 horas. Para a descalcificação dos tecidos foi utilizada solução à base de EDTA a $10 \%(\mathrm{pH} 7,4)$, na qual os tecidos foram mantidos submersos à temperatura ambiente por 30 dias. A solução de EDTA foi trocada a cada 7 dias para descalcificação completa, a qual foi testada por meio da avaliação da resistência do tecido a penetração de uma agulha na região do incisivo. Sequencialmente, as amostras foram lavadas em água corrente por 2 horas e submetidas à técnica histológica de rotina. Para tanto, as peças foram desidratadas em ordem crescente de álcoois (70\% por 45 minutos, 80\% por 45 minutos, 95\% por 45 minutos) e álcool absoluto I, II e III por uma hora cada. Para a diafanização as amostras foram colocadas por 30 minutos em solução de álcool e xilol (1:1) e finalmente em solução de xilol I, II e III por 40 minutos cada.

Os tecidos foram imersos em parafina fundida $\left(56\right.$ a $60^{\circ} \mathrm{C}$ ), mantidos em estufa por 4 horas e incluídos em blocos de parafina utilizando uma central de inclusão. Os blocos contendo as mandíbulas foram cortados longitudinalmente em micrótomo (Leica RM2145; Leica Microsystems GmbH, Wetzlar, Alemanha) no sentido vestíbulolingual. Seis lâminas de cortes seriados de $5 \mu \mathrm{m}$ foram obtidos em toda a extensão que incluiu as raízes do primeiro molar com o ápice aberto. Três cortes semi-seriados de três lâminas de cada grupo experimental foram corados com hematoxilina e eosina (HE) para análise histomorfométrica da reabsorção óssea apical. As lesões periapicais foram delineadas no ImageJ Software e suas áreas foram mensuradas em $\mathrm{mm}^{2}$. 
Para quantificação de osteoclastos, os outros três cortes semi-seriados de duas lâminas obtidos foram submetidos à reação de fosfatase ácida resistente ao tartarato - TRAP e contra-coradas com Hematoxilina. Os osteoclastos, os quais apresentaram coloração avermelhada e múltiplos núcleos, foram quantificados na região da lesão periapical do raiz distal do primeiro molar por meio de microscópio óptico (Nikon eclipse E200).

Cortes representativos de HE e TRAP foram fotografados com câmera AxioCam MRc5 acoplada ao microscópio Axio Imager.M1 (Carl Zeiss MicroImaging Gmbh, Göttingen, Alemanha).

\subsection{Avaliação da expressão gênica de marcadores de osteoclastos e de genes relacionados ao sistema imune}

Após o término dos períodos experimentais, foram coletados os linfonodos cervicais e as hemi-mandíbulas, os quais foram adicionados a $1 \mathrm{~mL}$ de TRI Reagent ${ }^{\circledR}$ (T9424- Sigma Life Science). Em seguida, foi realizada a trituração dos tecidos utilizando Polytron ${ }^{\circledR}$ (T10 basic ULTRA-TURRAX ${ }^{\circledR}$ - IKA) em alta rotação. O isolamento de RNA total das cultura de células, linfonodos e tecido mandibular foi realizado utilizando o Kit da Promega SV Total Isolation System (Z3105- Promega), de acordo com o cartão de protocolo 9FB025 indicado pelo fabricante. Após a extração, o RNA extraído foi eluído em $30 \mu$ de água Nuclease free e quantificado no aparelho nanofotômetro (NanoPhotometer $®$ P360, Implen, Inc., California, USA). Foi utilizado $1 \mu \mathrm{g}$ de RNA total para a síntese do cDNA por meio da reação de transcriptase reversa (High capacity cDNA Reverse Transcription kit da Applied Biosystems- 4368813). As amostras foram levadas ao termociclador (Eppendorf vapo.protect) e submetidas às seguintes temperaturas: $25^{\circ} \mathrm{C}$ por 10 minutos, $37^{\circ} \mathrm{C}$ por 120 minutos, $85^{\circ} \mathrm{C}$ por 5 minutos e $4^{\circ} \mathrm{C}$ até a remoção das amostras do aparelho. Após a realização da reação, as amostras foram diluídas 10 vezes e armazenadas em $-20^{\circ} \mathrm{C}$ até o momento do uso.

A reação de PCR para amplificação dos genes de interesse foi realizada utilizando os respectivos primers específicos (TaqMan ${ }^{\circledR}$ Gene Expression Assay) para marcadores de osteoclastos como TRAP (Acp5), V-ATPase (Atp6v0d2), Catepsina K (Ctsk), MMP-9 e fatores de transcrição de células T como o RORyt (Rorc), Foxp-3, 
GATA-3 e T-bet (Tbx21). Foi utilizado o reagente TaqMan ${ }^{\circledR}$ Fast Advanced Master MIX (4444557- Applied Biosystems ${ }^{\mathrm{TM}}$ ) e o equipamento de PCR em tempo real StepOnePlus $^{\mathrm{TM}}$ Real-Time PCR System (Applied Biosystems ${ }^{\mathrm{TM}}$ ).

Primers e sondas para Acp5 (Mm00475698_m1), Ctsk (Mm00484039_m1), MMP-9 (Mm00442991_m1), Atp6v0d2 (Mm01222965_m1), Tbx21 (Mm00450960_m1), Gata3 (Mm00484683_m1), Rorc (Mm01261022_m1), Foxp3 (Mm00475162_m1) foram obtidos comercialmente e as sequências são propriedades privadas do fornecedor (TaqMan® Gene Expression Assay, Applied Biosystems). 0 gene Gapdh (Mm99999915_g1) foi utilizado como gene endógeno.

A amplificação foi realizada em termociclador sob as seguintes condições: $50^{\circ} \mathrm{C}$ por 2 minutos para incubação, $95^{\circ} \mathrm{C}$ por 20 segundos para ativação da polimerase AmpliTaq Gold Enzyme, 40 ciclos de $95^{\circ} \mathrm{C}$ por 1 minuto para desnaturação do DNA e $60^{\circ} \mathrm{C}$ por 20 segundos para o anelamento do primer e a extensão.

Os resultados foram analisados com base no valor do ciclo limiar (Ct, cicle threshold), sendo este o ponto correspondente ao número do ciclo obtido na fase de amplificação exponencial das amostras que permite a análise quantitativa da expressão do gene avaliado.

O cálculo de expressão relativa dos genes foi normalizado pela expressão na condição controle, ou seja, pela diferença entre $\Delta \mathrm{Ct}$ das amostras (Ct do gene alvo Ct do gene endógeno constitutivo) e a média obtida do $\Delta \mathrm{Ct}$ dos animais controles, resultando os valores de $\Delta \Delta \mathrm{Ct}$ de cada animal. Em seguida, foi realizado o cálculo da expressão de cada gene avaliado com base na equação descrita pelo trabalho de Livak e Schmittgen (2001):

$$
\text { Expressão relativa }=2^{-\Delta \Delta C t}
$$

\subsection{Avaliação da atividade enzimática das metaloproteinases da matriz por Zimografia}

Para avaliação da atividade das gelatinolítica MMP-2 (68kDA) e MMP-9 (83kDA) nos tecidos periapicais, o lisado total do tecido ósseo mandibular foi obtido pela adição de tampão de lise (RIPA Buffer- Sigma-Aldrich) adicionados ao coquetel de inibidores de proteases, comercialmente disponíveis (Sigma- Aldrich), sendo 
sonicados por 15 minutos em gelo e centrifugado a $15000 \mathrm{rpm}$ por $15 \mathrm{~min}$ a $4^{\circ} \mathrm{C}$, conforme já padronizado no laboratório. A concentração de proteína foi determinada utilizando um kit comercial Pierce ${ }^{\mathrm{TM}}$ BCA Protein Assay Kit (Prod\#23225- Thermo Scientific). Cada amostra (contendo $20 \mu \mathrm{g}$ de proteína total) preparada com tampão não redutor foi deixado 5 minutos à $50^{\circ} \mathrm{C}$ para desnaturar as proteínas, em seguida, foi aplicada em um gel $7,5 \%$ de poliacrilamida em cuba de eletroforese de 200V/100mA, além do padrão molecular (PageRuler ${ }^{\mathrm{TM}}$ Prestained Protein Ladder Thermo Scientific) e o controle positivo. Após a separação das enzimas, o gel foi transferido para um reservatório contendo Triton X-100 a $2 \%$ por 30 minutos ( 2 vezes) em agitador horizontal para a permeabilização do gel. Sequencialmente, o gel foi deixado na estufa a $37^{\circ} \mathrm{C}$ em tampão de Tris com $\mathrm{CaCl}_{2}$, onde permaneceu durante 18 horas. Após esse período, este tampão foi substituído por um corante de Comassie Blue G-250 e levado ao agitador por 3 horas, sendo posteriormente colocado em solução de descorante com $20 \%$ metanol e $10 \%$ ácido acético até a melhor visualização das bandas. Por fim, as imagens do gel foram capturadas utilizando um Scanner (HP Deskjet Ink Advantage 4625) e quantificadas no programa de imagens ImageJ software.

\subsection{Análise estatística}

Os resultados foram expressos como média \pm erro padrão da média de no mínimo 5 animais por grupo. As análises dos resultados foram realizadas pelo teste $t$ de Student e pelo método de variância a um critério (One-way ANOVA), seguido de pós-teste de Bonferroni, conforme apropriado e de acordo com as variáveis e grupos comparados sendo que as diferenças consideradas significativas para valores de $\mathrm{P}<$ 0,05 foram determinadas utilizando GraphPad Software 5.0 (GraphPad Prism; GraphPad Software, San Diego). 
4. Resultados 



\section{RESULTADOS}

\subsection{Avaliação do modelo in vitro}

\subsubsection{Expressão gênica de marcadores de osteoclastos em cultura de células osteoclásticas após 72 horas de cultivo}

A expressão gênica de Trap e Catepsina $K$ foi avaliada em cultura de células provenientes da medula óssea de animais WT e animais NIrp12-/- após 72 horas de estímulo com M-CSF e RANKL.

Como pode ser observado na Figura 1, houve um aumento da expressão de Trap no grupo Nlrp12\%- quando comparados aos pré-osteoclastos de animais WT, contudo esse aumento não foi estatisticamente diferente. Da mesma forma, observase que a expressão de Catepsina K está aumentada no grupo Nlrp12-/- quando comparado ao grupo WT, sendo que o aumento não é estatisticamente significante.

Figura 1. Determinação da expressão gênica de Trap e Catepsina $K$ em osteoclastos. Cultura de células da medula óssea provenientes de animais WT e Nlrp12 ${ }^{-/}$estimulados com M-CSF (30 ng/mL) e RANKL (10 ng/mL) e coletados após 72 horas de cultivo. As células foram submetidas a avaliação da expressão gênica de Trap e Catepsina K por qPCR. Os valores de expressão são em relação à expressão do gene endógeno Gapdh. A barra indica média \pm desvio padrão da média.
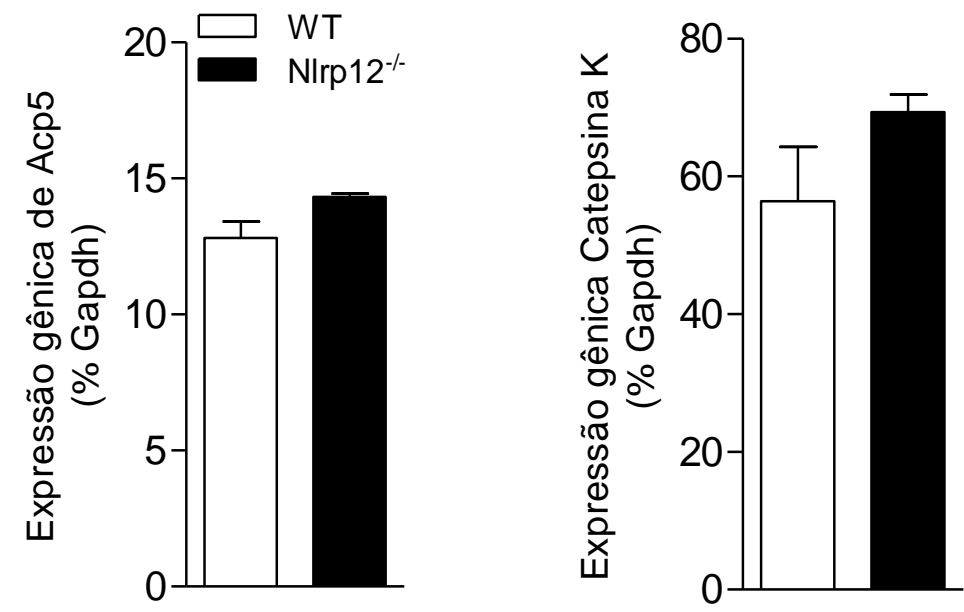

\subsubsection{Quantificação do número e tamanho dos osteoclastos após 96 horas de diferenciação}

Após um período de 96 horas de diferenciação foi realizada a coração das células pelo ensaio de TRAP. Os osteoclastos (células TRAP positivas contendo 3 ou mais núcleos) foram submetidos à contagem e à medição de sua extensão. Os préosteoclastos mantidos em meio com M-CSF, de ambos os grupos, apresentaram 
padrões semelhantes após 96 horas de cultura e as células não se diferenciaram em osteoclastos (Figura 2A e 2B). Por outro lado, quando os pré-osteoclastos foram cultivados com M-CSF e RANKL, observa-se um maior número de células TRAP positivas (marcadas em vermelho) no grupo Nlrp12\% (Figura 2D) quando comparado ao grupo WT (Figura 2C). 
Figura 2. Fotos representativas da cultura de osteoclastos. Após 96 horas de diferenciação, as células foram submetidas à coração com TRAP. As células provenientes de animais WT e NIrp12-1foram cultivadas na presença de M-CSF $(30 \mathrm{ng} / \mathrm{mL})$ em A e B, e de M-CSF $(30 \mathrm{ng} / \mathrm{mL})$ e RANKL $(10 \mathrm{ng} / \mathrm{mL})$ em C e D. Fotos fotografadas no aumento de 10x.

\section{WT}
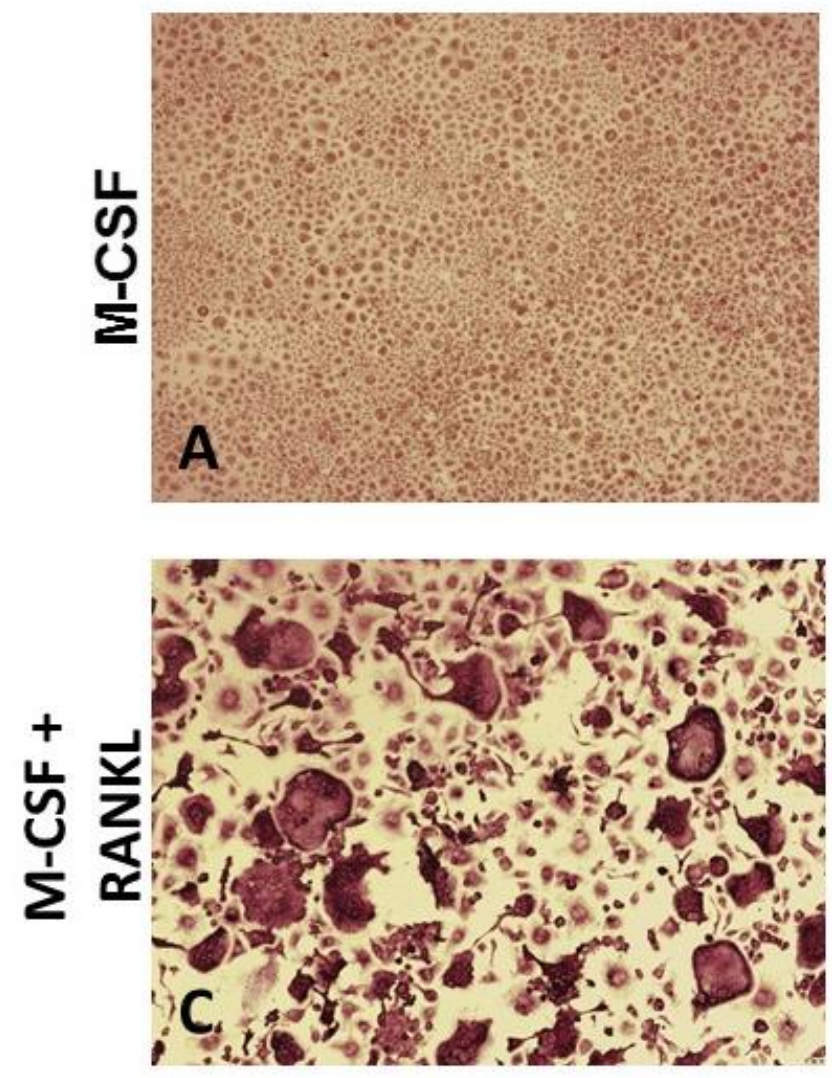

NIrp12-/-
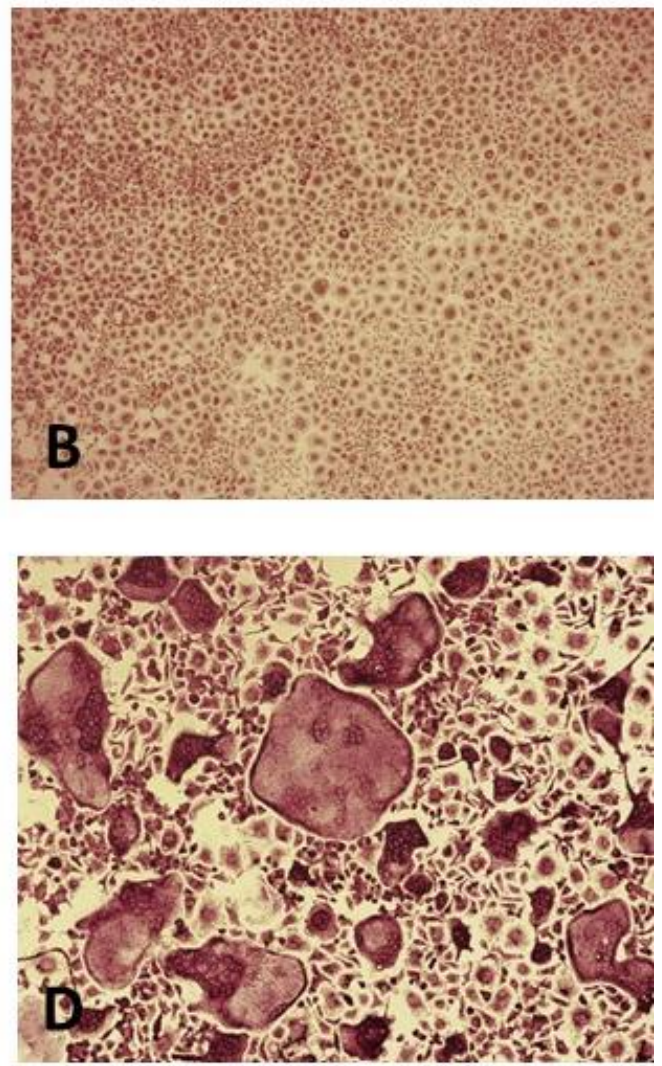

$\mathrm{Na}$ quantificação numérica dos osteoclastos observa-se que o grupo Nlrp12\%apresentou-se com um maior número quando comparados com o grupo WT (Figura 3). Além disso, ao avaliar a extensão dos osteoclastos no poço de cultura, observouse que osteoclastos do grupo $\mathrm{Nlrp}^{2-2^{-}}$apresentaram uma extensão significativamente maior em relação ao grupo WT (Figura 4).

Figura 3. Quantificação do número de osteoclastos in vitro. Avaliação do número de osteoclastos (contendo mais de três núcleos) do grupo WT e Nlrp12-- com M-CSF (M) ou M-CSF e RANKL (MR), após 96 horas de cultivo. A barra indica média \pm desvio padrão da média. ${ }^{\#} \mathrm{P}<0,05$ e $* * * P<0,0001$ indicam diferença estatisticamente significante, avaliado por One-way ANOVA, seguido pelo pós-teste de Bonferroni.

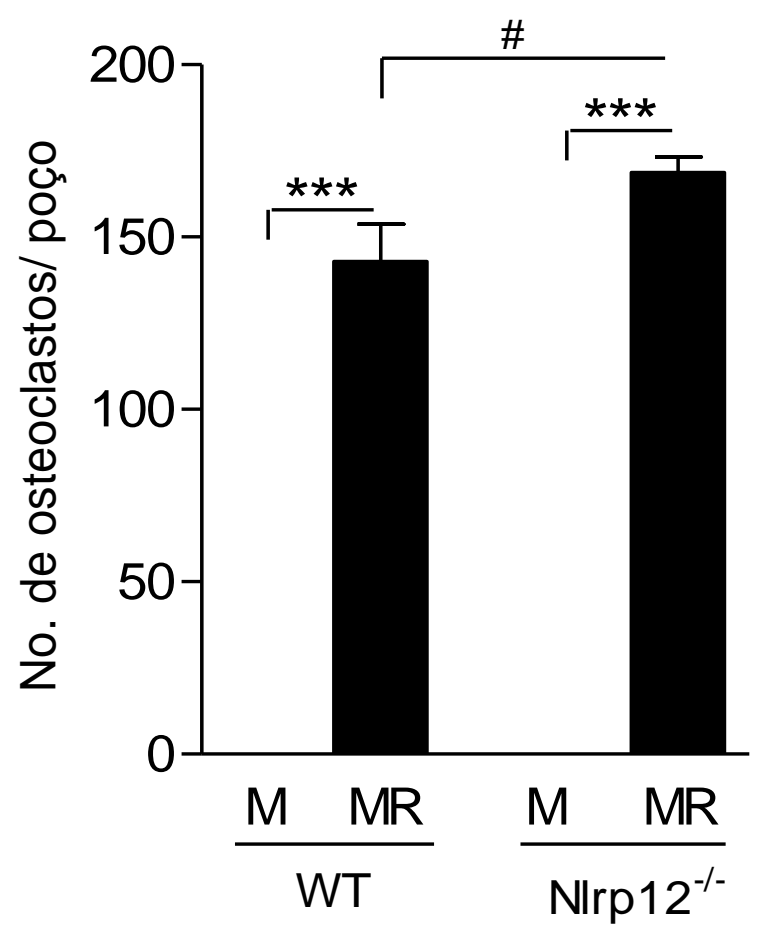


Figura 4. Determinação da área dos osteoclastos in vitro. Avaliação da extensão dos osteoclastos de células provenientes de animais WT e deficientes para Nlrp12 com M-CSF $(30 \mathrm{ng} / \mathrm{mL})$ e RANKL $(10 \mathrm{ng} / \mathrm{mL})$, após 96 horas de diferenciação. A barra indica média \pm desvio padrão da

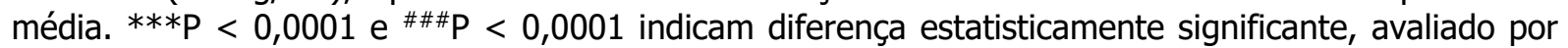
One-way ANOVA, seguido de pós-teste de Bonferroni.

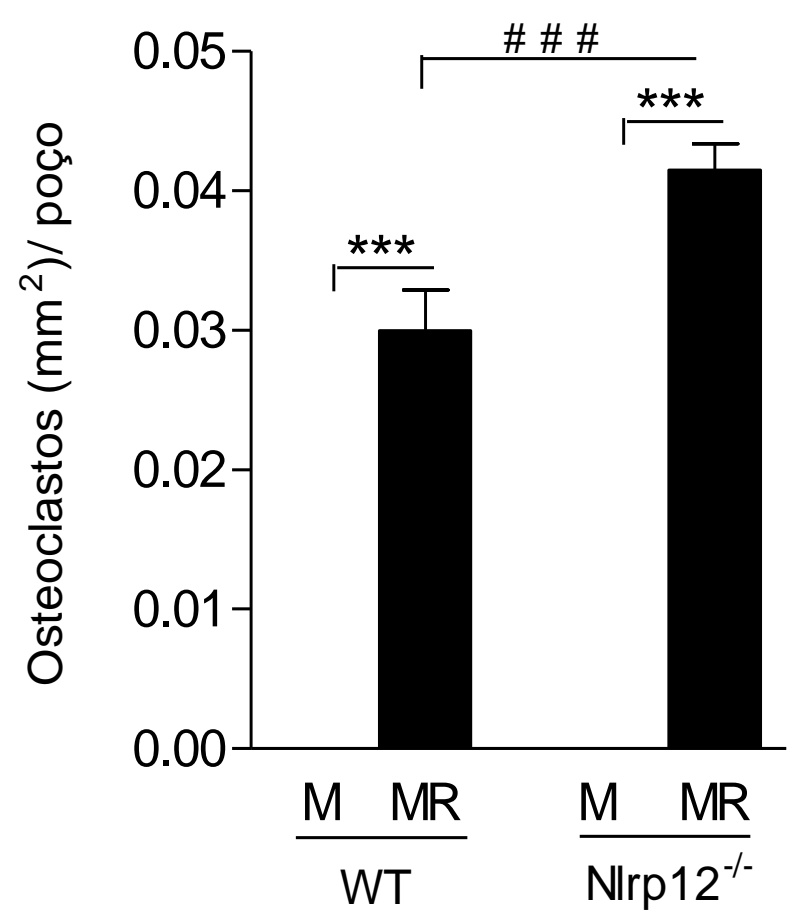

\subsection{Avaliação do modelo in vivo}

\subsubsection{Participação do receptor NLRP12 na modulação da reabsorção óssea durante a periodontite apical induzida}

Considerando que no modelo in vitro, a cultura de osteoclastos provenientes de animais NIrp12-/- apresentou maior número de osteoclastos em relação ao WT, avaliamos se esse efeito poderia ser extrapolado para um modelo de reabsorção óssea in vivo. Para isso, foi realizada o modelo de lesão periapical em animais WT e Nlrp12 ${ }^{-/}$, onde a cavidade oclusal do dente foi exposta e infectada naturalmente pela microbiota oral. Primeiramente foi efetuado a avaliação histomorfométrica da lesão periapical na raiz distal do primeiro molar inferior após 14 dias de indução.

A figura 5 mostra os cortes representativos dos grupos controle e com lesão apical dos animais WT e NIrp12\% aos 14 dia de lesão. Pode-se observar que os grupos controles de ambos os grupos apresentaram um tecido pulpar sadio, 
ligamento periodontal com fibras e células organizadas, superfície cementária regular, ausência de infiltrado inflamatório e osso alveolar íntegro.

Nos grupos submetidos a exposição pulpar foram observados padrões semelhantes de necrose do tecido pulpar, perda do ligamento periodontal e fibras desorganizadas, tanto no grupos WT quanto NIrp12\%. No entanto, percebe-se características distintas em relação a superfície cementária entre os mesmos. Os animais NIrp12 ${ }^{--}$apresentaram uma superfície mais irregular que os animais WT, ou seja, uma maior reabsorção cementária. Sendo assim, foi realizada a medição de toda a extensão do processo inflamatório e consequentemente a perda de tecido ósseo, cemento e ligamento periodontal ao redor do ápice, avaliados em três lâminas com três cortes semi-seriados de cada animal.

De fato, os animais WT e NIrp12\% com lesão apresentaram uma maior extensão de perda óssea apical quando comparados com seus respectivos controles. E de forma esperada, os animais Nlrp12\%- apresentaram uma maior perda óssea, com significância, quando comparados aos animais WT (Figura 6). 

Figura 5. Fotos representativas de cortes corados com HE aos 14 de lesão. Cortes histológicos representativos, corados com hematoxilina \& eosina, da região periapical da raiz distal do primeiro molar inferior esquerdo (controles) e direito (com lesão periapical induzida) de animais WT e Nlrp12 ${ }^{--}(n=6)$. (A) WT Controle, (B) WT Lesão periapical, (C) Nlrp12 ${ }^{--}$Controle, (D) Nlrp12 ${ }^{--}$Lesão periapical. Barra $=0,2 \mathrm{~mm}$. As peças foram fotografadas no aumento de $10 \mathrm{x}$.

\section{DIAS}
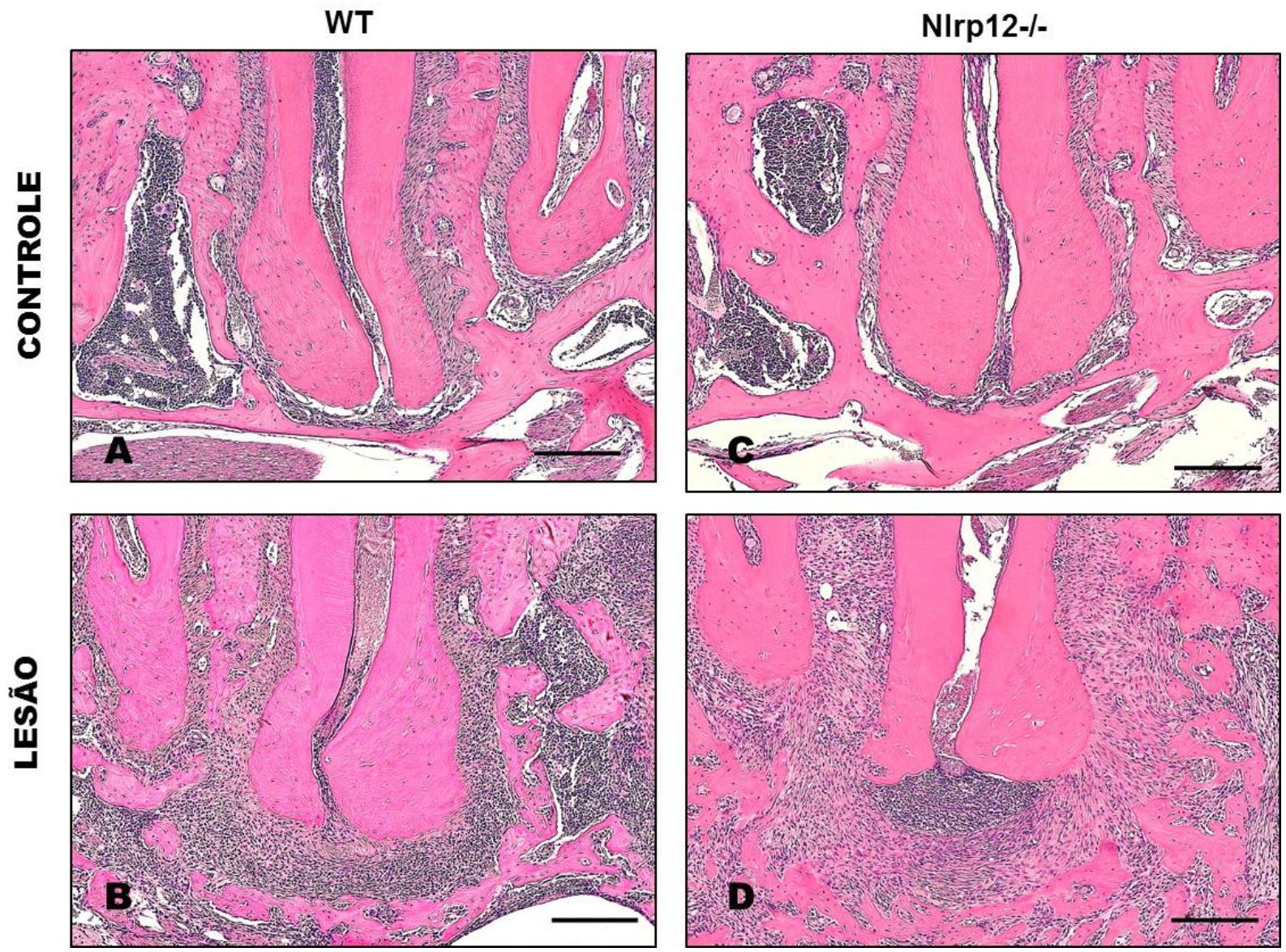

Figura 6. Determinação do tamanho da lesão periapical por histomorfometria após 14 dias de lesão. Avaliação da área da lesão periapical em $\mathrm{mm}^{2}$ nas amostras de hemi-mandíbulas após a indução da lesão periapical. Os cortes foram corados com HE. Três lâminas de cada animal com três cortes seriados foram submetidas a contagem $(n=6)$. A barra indica média \pm desvio padrão da média. $* * \mathrm{P}<0,01, * * * \mathrm{P}<0,0001$ e ${ }^{\#}<0,05$ indicam diferença estatisticamente significante, avaliado por One-way ANOVA, seguido de pós-teste de Bonferroni.

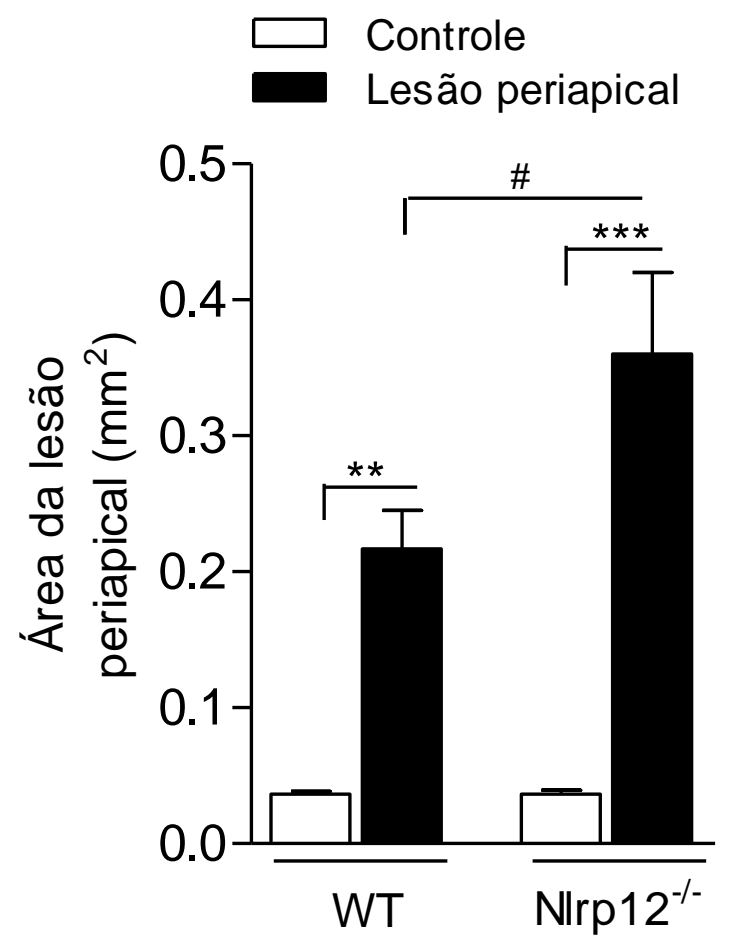

No período de 14 dias de indução da lesão, foi observado que os animais Nlrp12-/- apresentaram uma lesão periapical mais extensa quando comparados com os animais WT, mostrando que o receptor NLRP12 possui um papel importante na modulação do desenvolvimento e da progressão da doença em seus estágios iniciais. Sendo assim, para determinar se animais Nlrp12 ${ }^{-/}$continuariam apresentando uma maior perda dos tecidos periapicais que os animais WT em fases mais tardias, foi realizada também a avaliação histomorfométrica no período de 21 dias pós-indução da lesão. Como pode observar na Figura 7, os grupos controle mostraram características similares com o período de 14 dias, já descritos acima. Nota-se que ambos os grupos com lesão periapical apresentaram uma grande quantidade de infiltrado inflamatório, seguidos de perda do ligamento periodontal e desorganização das fibras. Além disso, neste período houve uma redução do trabeculado ósseo na região apical do dente envolvido, sugerindo uma evolução da doença. Sendo assim, foi realizada a mensuração das áreas das lesões e nas amostras controles, a região 
que compreende o ligamento periodontal apical sadio foi mensurada como área controle. Nesta fase da doença, tanto o grupo WT quanto o Nlrp12-- mostrou uma maior perda óssea em relação aos seus respectivos controles, no entanto, o grupo WT e Nlrp12 ${ }^{--}$submetidos ao modelo experimental se igualaram no tamanho da lesão (Figura 8). 
Figura 7. Fotos representativas de cortes corados com HE aos 21 dias de lesão. Cortes histológicos representativos corados com hematoxilina e eosina da região periapical da raiz distal do primeiro molar inferior esquerdo (controles) e direito (com lesão periapical induzida) de animais WT e Nlrp12- $(n=6)$. (A) WT Controle, (B) WT Lesão periapical, (C) Nlrp12\%-Controle, (D) Nlrp12 ${ }^{-/-}$Lesão periapical. Barra $=0,2 \mathrm{~mm}$. As peças foram fotografadas no aumento de $10 \mathrm{x}$.

\section{DIAS}
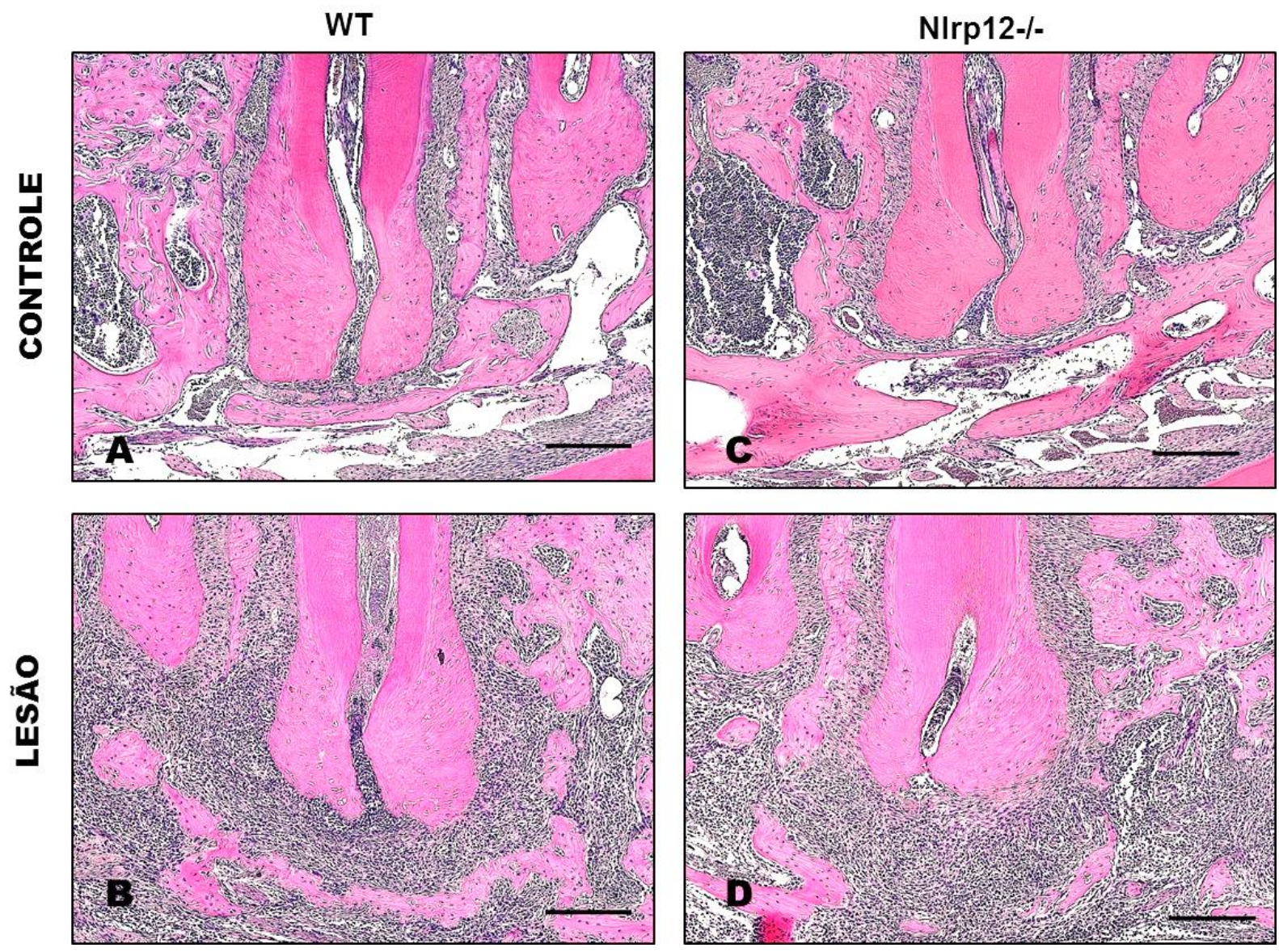

Figura 8. Determinação da área da lesão periapical aos 21 dias por histomorfometria. Foi avaliada a extensão da lesão periapical nas amostras de hemi-mandíbulas coradas com HE. Três lâminas de cada animal com três cortes seriados foram submetidas a contagem $(n=6)$. A barra indica média \pm desvio padrão da média. $* * * P<0,0001$ indica diferença estatisticamente significante, avaliado por One-way ANOVA, seguido de pós-teste de Bonferroni.

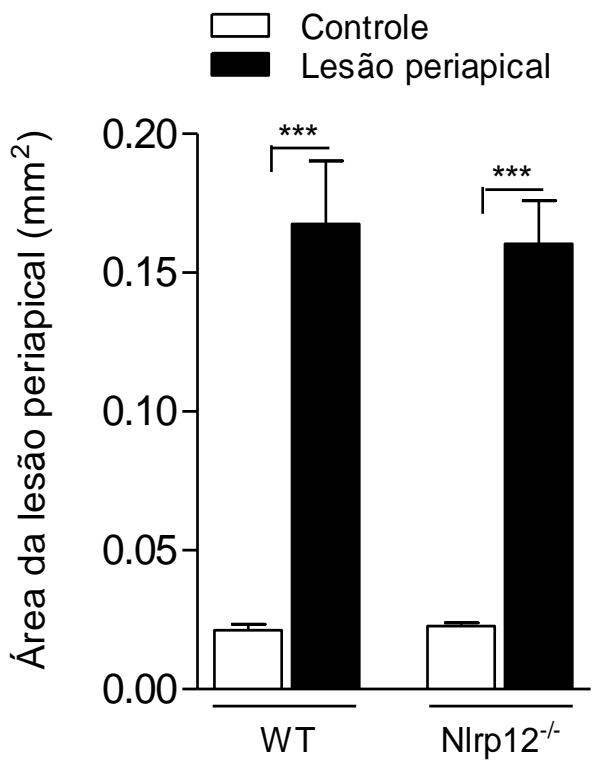

\subsubsection{Expressão gênica de marcadores de células $\mathrm{T}$ em linfonodos cervicais}

Visto que a deficiência de NLRP12 levou a uma maior perda óssea apical em relação aos animais WT, foi avaliado se a participação desse receptor era mediado via regulação do processo inflamatório. Sabe-se que a resposta imune está intimamente relacionada com o processo de reabsorção óssea, e que linfonodos próximos à região da lesão periapical coordenam a resposta frente ao processo inflamatório/infeccioso (Takahashi et al., 1999 e Tasman et al., 2000). Sendo assim, os subtipos de células $T$ presentes nos linfonodos cervicais foram avaliados pela análise da expressão de seus marcadores específicos.

Foi avaliado a expressão gênica de T-bet (9A), Gata-3 (9C) e Foxp-3 (9D), os quais são fatores de transcrição de células Th1, Th2 e células T reguladoras (Treg), respectivamente. Dentre os marcadores de células $\mathrm{T}$ avaliados, a expressão de T-bet foi significantemente menor nos animais NIrp12\% (9A). Além disso o grupo NIrp12 $2^{-1}$ apresentou uma tendência a menor expressão Gata-3 e Foxp-3 quando comparados com o grupo WT (Figura 9C e 9D), embora sem significância. 
Também foi avaliada a expressão de Roryt (9B), fator de transcrição de células Th17, conhecidas por estimular a diferenciação dos osteoclastos. Aos 14 dias de lesão, pode-se observar uma tendência ao aumento da expressão de Roryt no grupo Nlrp12\%, todavia não houve diferença significativa entre os grupos (Figura 9).

Figura 9. Determinação da expressão gênica de marcadores de células $T$ aos 14 dias. Avaliação da expressão gênica dos fatores de transcrição T-bet (A), Roryt (B), Gata-3 (C) e Foxp-3 (D) por qPCR em amostras de linfonodos cervicais de animais WT e Nlrp12\% após a indução da lesão periapical. Os resultados dos genes avaliados foram em relação à expressão do gene endógeno Gapdh. A barra indica média \pm desvio padrão da média. $* \mathrm{P}<0,05$ indica diferença estatisticamente significante, avaliados por teste t de Student.

\section{DIAS}

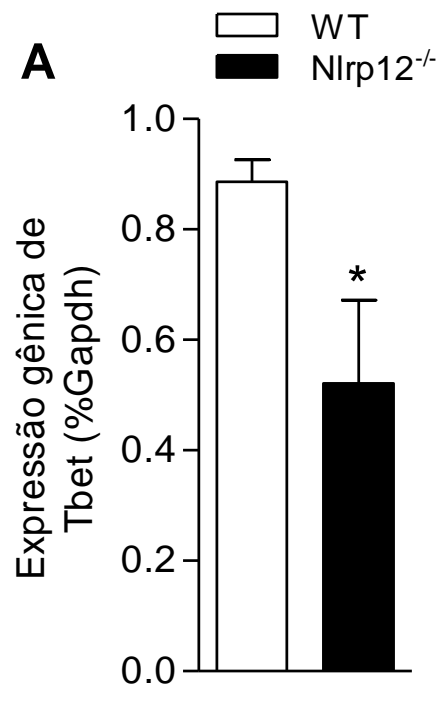

B

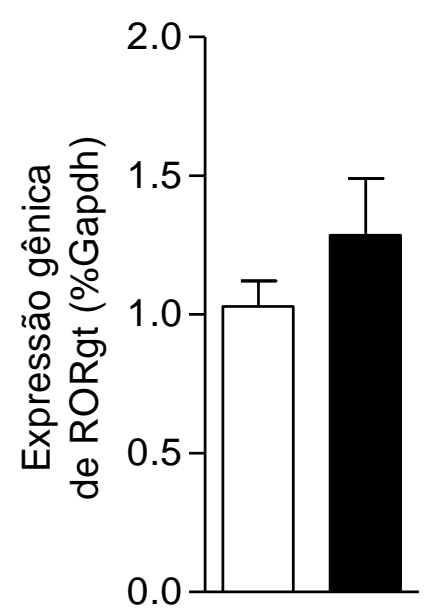

C

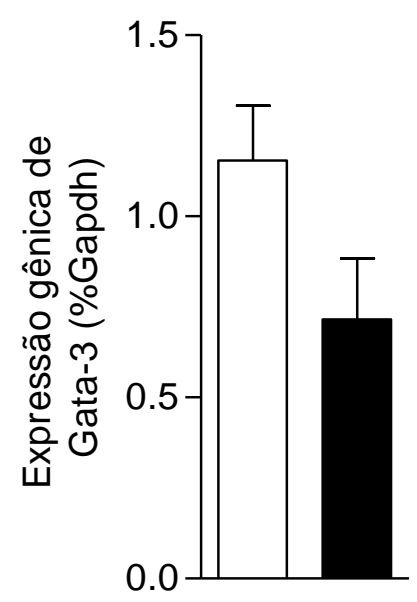

D

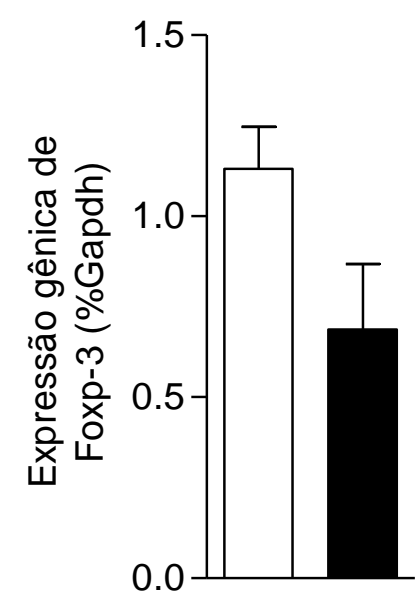


Após 21 dias de lesão periapical, os mesmos genes marcadores de células T foram avaliados nos linfonodos cervicais dos animais WT e Nlrp12 $\%$. Neste período, pode-se observar que os níveis de expressão de Roryt nos animais Nlrp12\% ainda mantiveram-se aumentados em relação aos animais WT, embora não apresente significância. E quando avaliamos a expressão de T-bet, Gata-3 e Foxp-3, os níveis de expressão gênica dos mesmos desta vez, apresentaram-se aumentados nas amostras do Nlrp12\%, contudo sem significância. (Figura 10).

Figura 10. Avaliação da expressão gênica dos fatores de transcrição de células $\mathbf{T}$ aos $\mathbf{2 1}$ dias de lesão. Determinação da expressão gênica de fatores de transcrição T-bet (A), RORyt (B), Gata-3 (C) e Foxp-3 (D) nas amostras de linfonodos cervicais de animais WT e Nlrp12-\%. Os valores de expressão são em relação à expressão do gene endógeno Gapdh. A barra indica média \pm desvio padrão da média, avaliados por teste t de Student.

\section{DIAS}

A

B
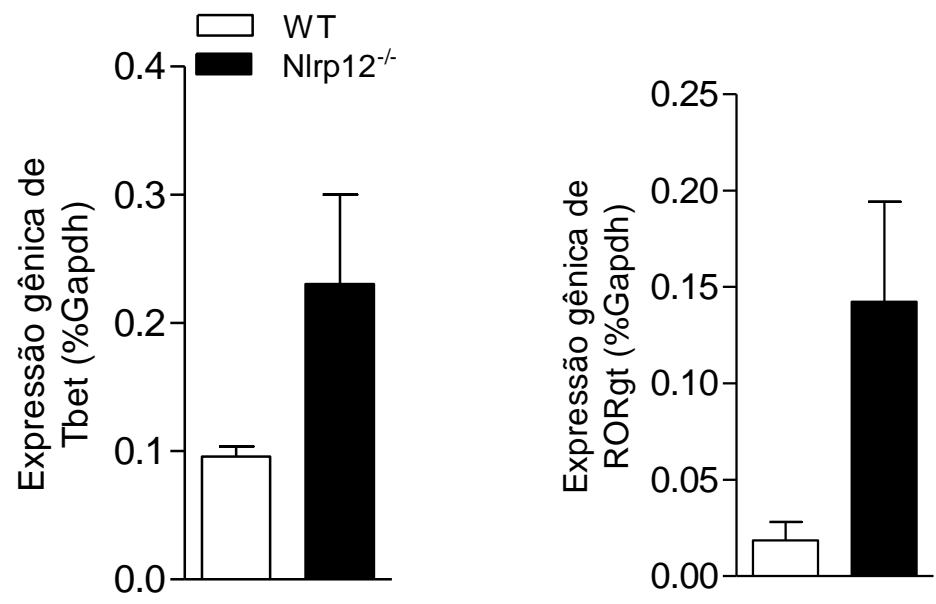

C

D
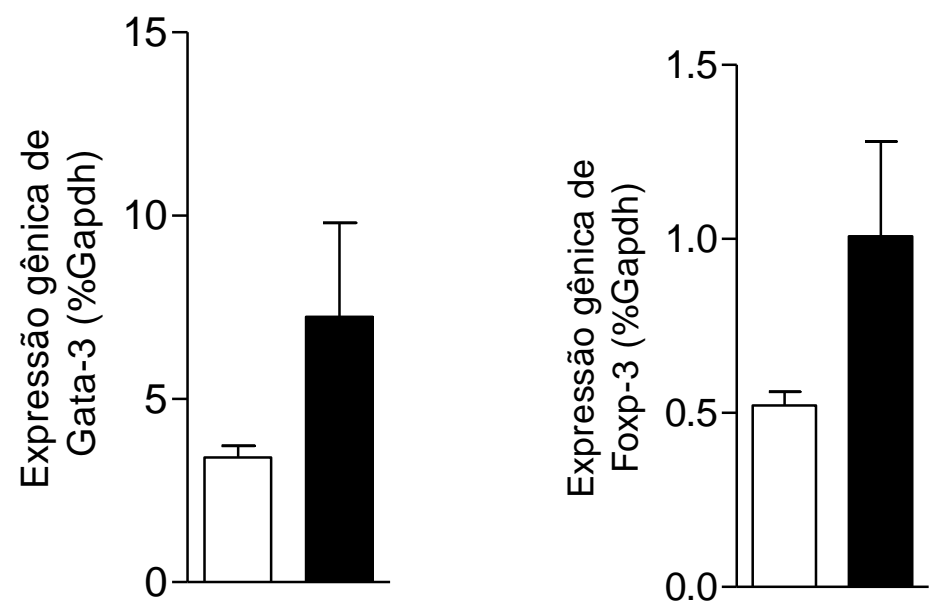


\subsubsection{Expressão gênica de marcadores de osteoclastos em hemi- mandíbulas após a indução da lesão periapical}

Até o presente momento, vimos que a modulação da reabsorção óssea durante o desenvolvimento da lesão periapical pelo NLRP12 pode ocorrer via participação de células $T$, sendo que estas podem atuar de forma indireta na diferenciação e ativação dos osteoclastos.

Como visto no estudo in vitro, NLRP12 mostrou exercer um papel importante na modulação óssea, uma vez que a deficiência de NLRP12 levou a uma maior formação de osteoclastos em relação ao grupo WT. Sendo assim, foi realizada a avaliação da expressão gênica de marcadores osteoclastogênicos e de atividade de osteoclastos em hemi-mandíbulas de animais WT e Nlrp12 ${ }^{-/}$submetidos ao modelo de lesão periapical. Os dados histológicos foram compatíveis aos dados moleculares com base na expressão de Trap, Catepsina K e MMP-9. A Figura 5 mostra que, aos 14 dias após a indução da lesão periapical, a expressão de Trap foi significativamente maior no lado com lesão quando comparados aos seus respectivos lados controles (sem lesão). Este efeito foi observado tanto nos animais WT quanto Nlrp12 ${ }^{-/}$. Foi observado ainda, que a expressão gênica de Trap nos animais NIrp12\%com lesão foi significativamente maior em relação aos animais WT com lesão (Figura $11 \mathrm{~A})$.

Além disso, a avaliação da expressão gênica de outros marcadores de osteoclastos mostrou que o grupo Nlrp12\% com lesão apresentou uma expressão maior de Catepsina K e MMP-9 em relação ao seu controle e que os mesmos também apresentaram maiores níveis de expressão de ambos quando comparados aos animais WT com lesão (Figuras 11B e11C).

Por outro lado, somente o grupo Nlrp12\% com lesão apresentou maior expressão de V-ATPase, que o seu grupo controle (Figura 11D). 
Figura 11. Determinação da expressão gênica de marcadores de osteoclastos aos 14 dias de lesão. Avaliação da expressão gênica de Trap (A), Catepsina K (B), MMP-9 (C) e V-ATPase (D) nas amostras de hemi-mandíbulas de animais WT e Nlrp12 $2^{--}$após a indução da lesão periapical. Os valores de expressão são em relação à expressão do gene endógeno Gapdh, seguidos dos seus respectivos controles. A barra indica média \pm desvio padrão da média. ${ }^{* *} P<0,01,{ }^{* *} P<0,0001$ e ${ }^{\#} P$ $<0,05$ indicam diferença estatisticamente significante, avaliados por One Way ANOVA, seguido de pós-teste de Bonferroni.

\section{DIAS}
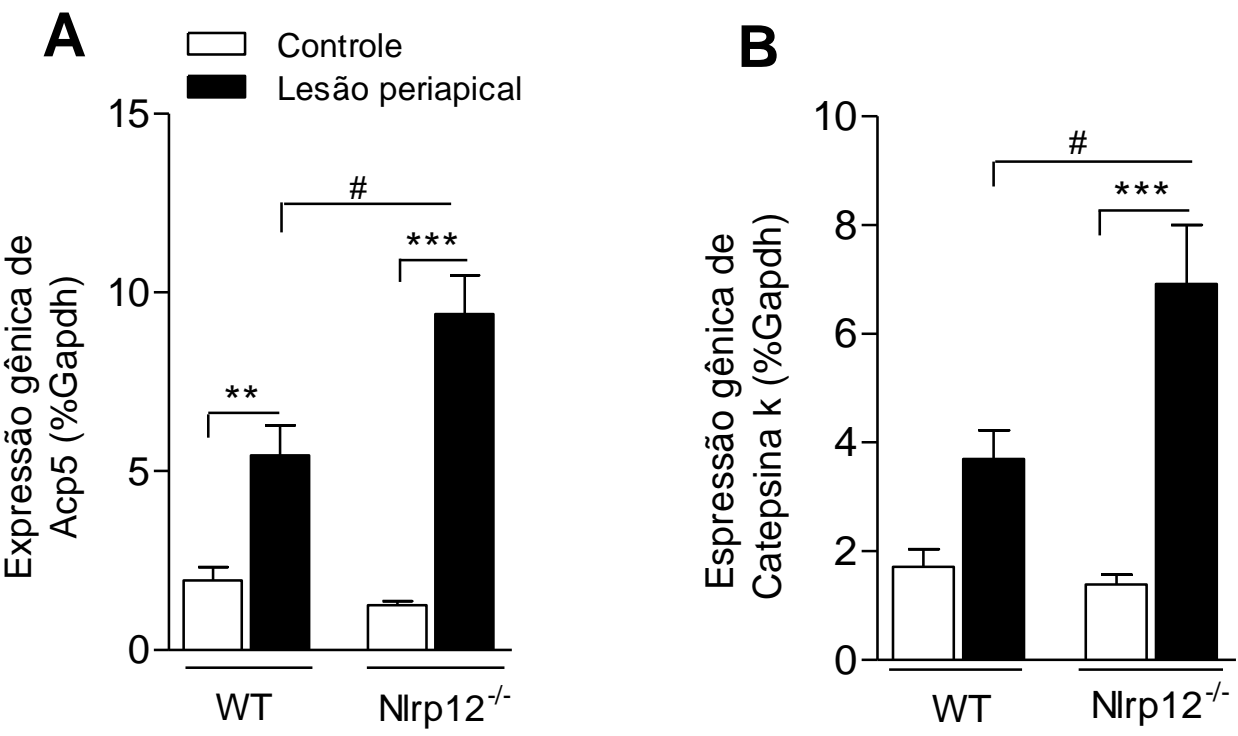

C
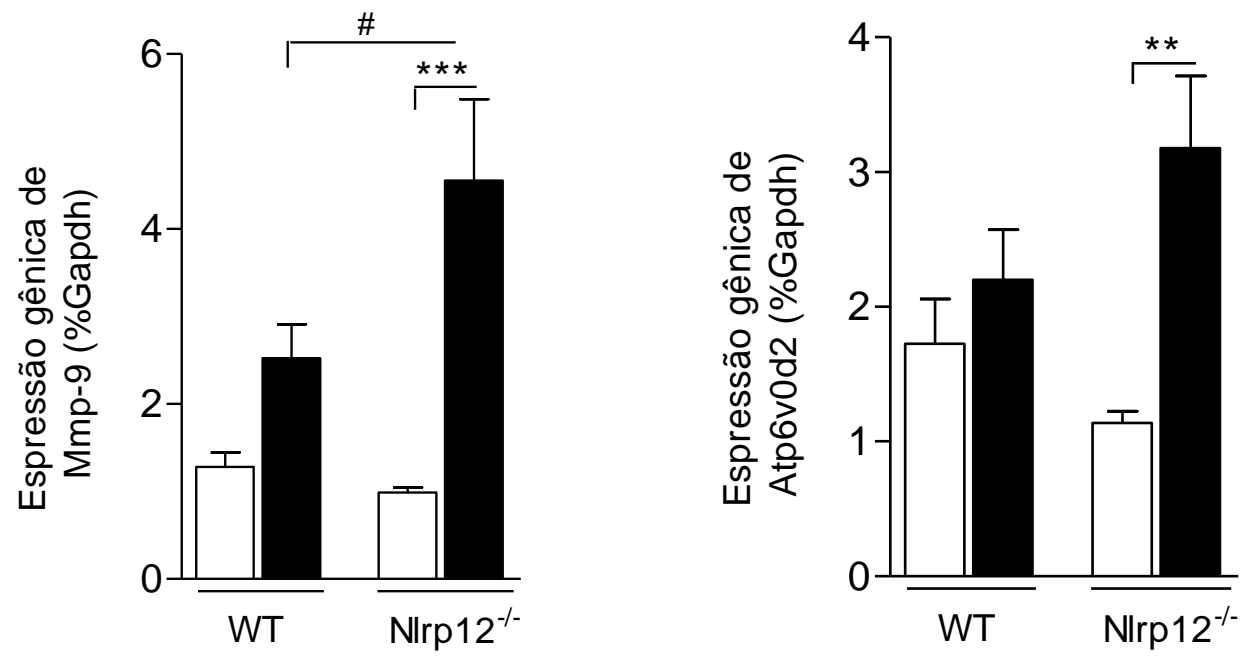

Concomitantemente foi avaliada a expressão dos marcadores de osteoclastos nas amostras de 21 dias de lesão. Observou-se um aumento da expressão de Trap no lado com lesão do grupo Nlrp12\% quando comparado ao lado sem lesão. Este efeito não foi observado nos animais WT. Neste período pós lesão, observou-se que não houve diferença na expressão de Trap entre os grupos NIrp12\%- e WT com lesão, 
embora observa-se que no grupo Nlrp12\% com lesão houve uma tendência de maior expressão de Trap (Figura 12A).

Foi avaliado também, a expressão gênica de Catepsina $K$, um marcador de atividade dos osteoclastos, nas amostras de hemi-mandíbulas após 21 dias de lesão periapical. Observou-se que houve um aumento nos grupos com lesão em relação aos seus respectivos controles, porém esse aumento não foi significativo em ambos os grupos WT e Nlrp12-- (Figura 12B).

Figura 12. Avaliação dos marcadores de osteoclastos por qPCR aos 21 dias de lesão. Avaliação da expressão gênica de Trap (A) e Catepsina K (B) nas amostras de hemi-mandíbulas de animais WT e Nlrp12 $2^{-/}$. Os valores de expressão são em relação à expressão do gene endógeno Gapdh, seguidos dos seus respectivos controles. A barra indica média \pm desvio padrão da média. ${ }^{* *} P$ $<0,01$ indica diferença estatisticamente significante, avaliados por One Way ANOVA, seguido de pósteste de Bonferroni.

\section{DIAS}
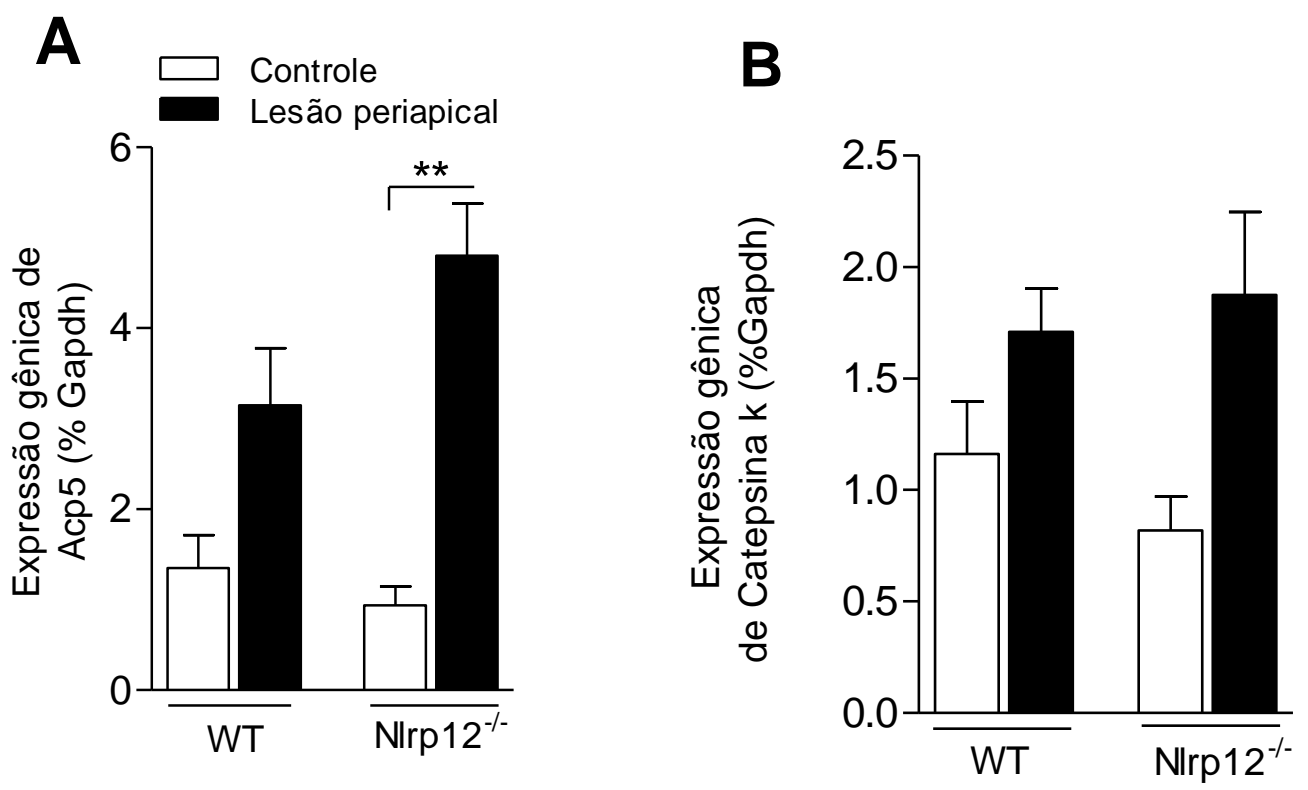

\subsubsection{Determinação do número de osteoclastos pelo ensaio enzimático de TRAP}

Uma vez visto que a expressão gênica de marcadores de osteoclastos estavam aumentados no grupo Nlrp12\% com lesão quando comparados com o grupo WT com lesão, foi analisada a quantidade de osteoclastos presentes na região de periápice.

Para isso, foi realizado o ensaio enzimático de TRAP nas lâminas histológicas. A Figura 13 mostra imagens representativas de cada grupo experimental e seus controles com indicações dos osteoclastos marcados em vermelho por TRAP. Pode-se observar que os grupos controles apresentaram 
reduzido número de células TRAP- positivas na região periapical. Por outro lado, os grupos com lesão apresentaram várias marcações ao redor da lesão formada, principalmente entre as trabéculas ósseas. Ao quantificá-los, foi observado um maior número de osteoclastos presentes na região periapical do grupo NIrp12 ${ }^{-/-}$em relação ao seu controle. E quando avaliamos o grupo WT com lesão, este mostrou ter mais osteoclastos em relação ao seu grupo controle, porém sem diferença significativa (Figura 14). 

Figura 13. Fotos representativas de cortes corados com TRAP aos 14 dias de lesão. Foi avaliado o número de células TRAP positivas na região periapical da raiz dista do primeiro molar inferior esquerdo (controles) e direito (com lesão periapical induzida) de animais WT e Nlrp12 ${ }^{--}$, como indicados pelas setas. (A) WT Controle, (B) WT Lesão periapical, (C) Nlrp12 ${ }^{--}$Controle, (D) NIrp12\%Lesão periapical. Os cortes foram fotografados no aumento de 10x.

\section{DIAS}
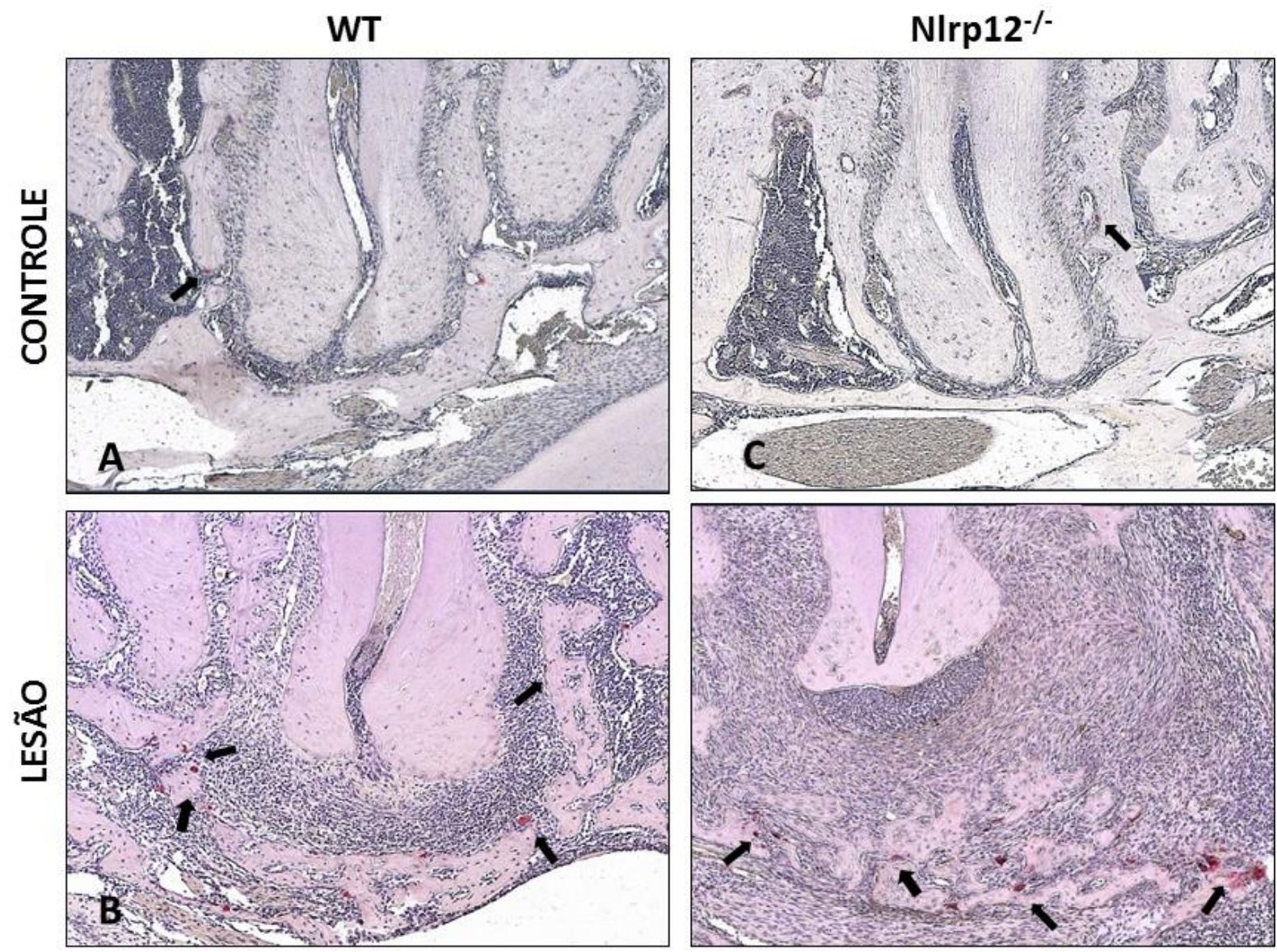

Figura 14. Após 14 dias de lesão, quantificação das células marcadas com TRAP. As células marcadas com coloração vermelha presentes na região da lesão periapical foram submetidas à contagem. Três lâminas de cada animal com três cortes seriados foram submetidas a contagem. A barra indica média \pm desvio padrão da média. ${ }^{*} \mathrm{P}<0,05$ indica diferença estatisticamente significante, avaliados por One Way ANOVA, seguido de pós-teste de Bonferroni.

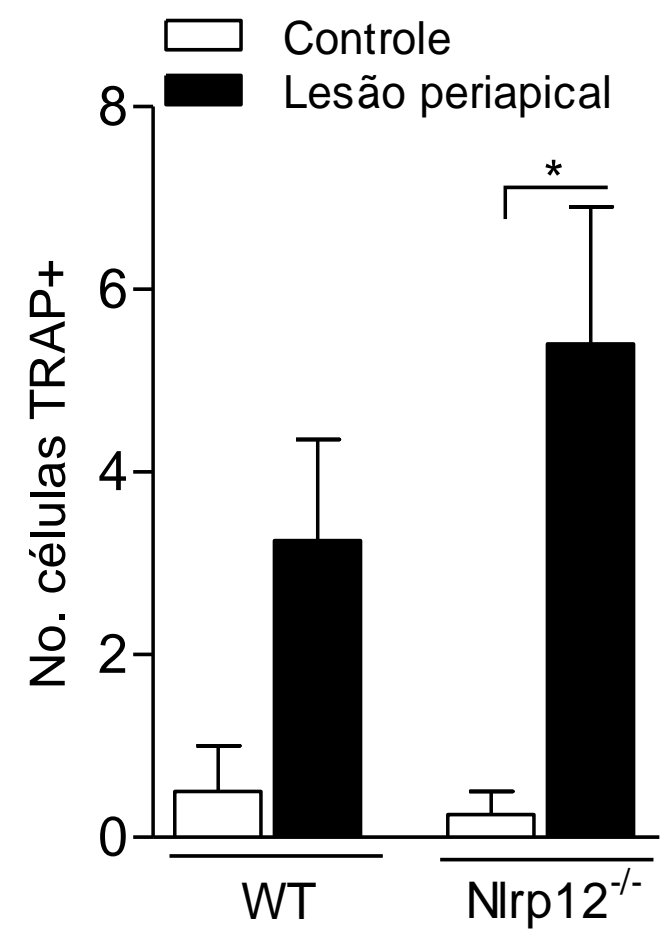

Assim como aos 14 dias, também foi realizada a avaliação dos osteoclastos presentes na região periapical após 21 dias de lesão conforme indicado na Figura 15. Todas as células TRAP positivas no local da lesão periapical foram submetidas à contagem. Ao observar as imagens abaixo, verifica-se que os grupos controles continuaram apresentando um número muito reduzido de osteoclastos quando comparados com seus respectivos grupos com lesão. Do mesmo modo, foram encontrados várias marcações TRAP positivas tanto nos cortes do grupo WT quanto no grupo Nlrp12\%, ambos com lesão. Observou-se que, em relação aos seus respectivos grupos controles, houve um maior número de osteoclastos em ambos os grupos com lesão, todavia quando comparamos os grupos WT e NIrp12\%- com lesão, foi observado que o aumento entre eles foi semelhante (Figura 16). 

Figura 15. Fotos representativas de cortes corados com TRAP aos $\mathbf{2 1}$ dias de lesão. As células TRAP positivas indicadas pelas setas na região periapical da raiz dista do primeiro molar inferior esquerdo (controles) e direito (com lesão periapical induzida) de animais WT e NIrp12\%, foram

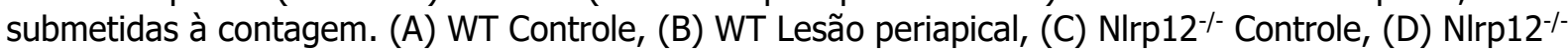
Lesão periapical. Os cortes são de lesões periapicais com 21 dias e estes foram fotografados no aumento de 10x.

\section{DIAS}
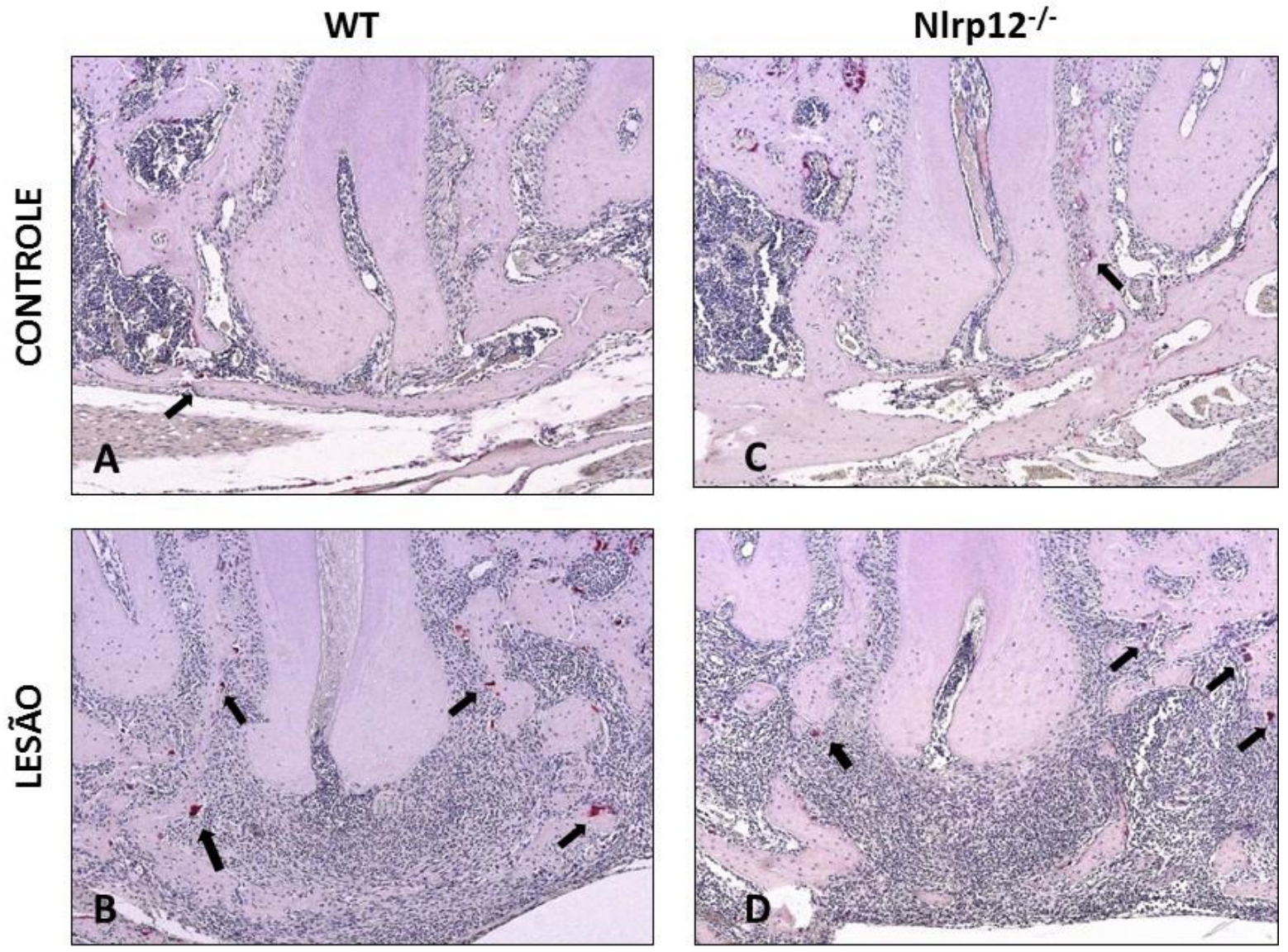

Figura 16. Quantificação das células TRAP positivas com 21 de lesão. Três lâminas de cada animal com três cortes seriados foram submetidas a contagem. Foram contados as células que apresentaram marcação positiva para coloração Trap na região da lesão periapical. A barra indica média \pm desvio padrão da média. ${ }^{*} * \mathrm{P}<0,01$ e $* * * \mathrm{P}<0,0001$ indicam diferença estatisticamente significante, avaliado por One Way ANOVA, seguido de pós-teste de Bonferroni.

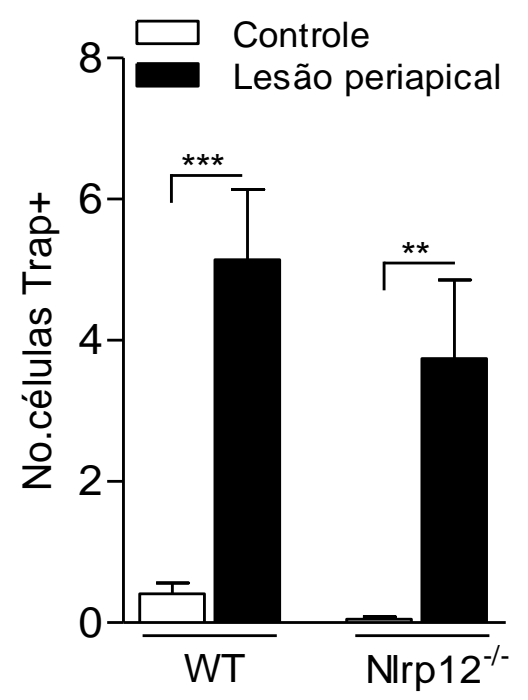

\subsubsection{Avaliação da atividade proteolítica das enzimas responsáveis pela degradação da matriz extracelular durante a reabsorção óssea}

Sabe-se que o processo de reabsorção óssea inicia-se com a liberação de enzimas que degradam os componentes orgânicos, como o colágeno, e dentre as enzimas responsáveis pela degradação da matriz extracelular estão as metaloproteinases da matriz 2 e 9 (MMP-2 e MMP-9). Sendo assim, a fim de avaliar a atividade dos osteoclastos presentes nos tecidos periapicais, foi realizada a avaliação gelatinolítica de MMP-9 e MMP-2 por Zimografia (Figura 17).

No grupo experimental de 14 dias de lesão foi observado um aumento significativo da atividade de MMP-9 (17A) no grupo Nlrp12-- com lesão, em relação ao seu grupo controle. Entretanto, quando avaliada a atividade dessa mesma enzima entre os grupos WT com e sem lesão, eles se mostraram semelhantes. Ainda na avaliação da atividade de MMP-2, a Figura 17 B mostra uma maior atividade desta enzima no grupo Nlrp12\%- com lesão, em relação a seu controle, porém o grupo WT com lesão não mostrou uma mudança da atividade de MMP-2 em relação ao seu controle. 
Figura 17. Avaliação da atividade proteolítica das metaloproteinases. Foi avaliado a atividade proteolítica de MMP-9 (A) e MMP-2 (B) nas amostras de hemi-mandíbulas aos 14 dias após a indução da lesão periapical, por Zimografia. A barra indica média \pm desvio padrão da média. ${ }^{* * P}<0,01$ indica diferença estatisticamente significante, avaliados por One Way ANOVA, seguido de pós-teste de Bonferroni.

\section{DIAS}
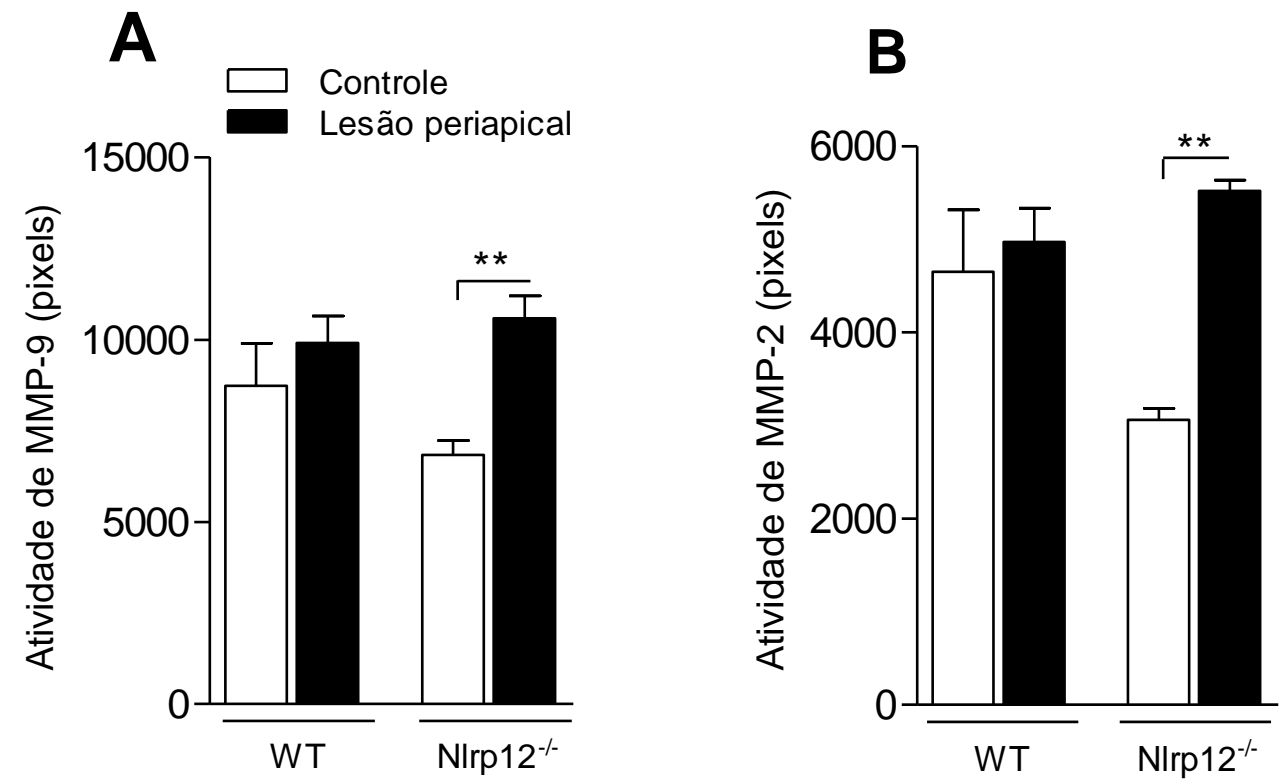

Foi avaliada a atividade das enzimas MMP-9 e MMP-2 nas amostras de hemimandíbulas no período de 21 dia após a lesão (Figura 18). Nesta fase mais tardia da doença, não houve diferença de atividade enzimática de MMP-9 (18A) entre os grupos WT e Nlrp12 ${ }^{-/}$com lesão, além disso os mesmos se mostraram semelhantes em relação aos seus respectivos controles. Da mesma forma, na avaliação da atividade de MMP-2 (18B), observou-se que o grupo WT com lesão, apesar de mostrar uma atividade maior de MMP-2 quando comparado com seu controle, esse aumento não foi significante. Da mesma forma, o grupo $\mathrm{NIrp}^{-/-}$com lesão se mostrou semelhante em relação ao seu controle aos 21 dias de lesão. 
Figura 18. Avaliação da atividade enzimática de MMP-9 e MMP-2. Avaliação da atividade proteolítica de MMP-9 (A) e MMP-2 (B) nas amostras de hemi-mandíbulas aos 21 dias após a indução da lesão periapical, pela técnica de Zimografia. A barra indica média \pm desvio padrão da média. Dados avaliados por One Way ANOVA, seguido de pós-teste de Bonferroni.

\section{DIAS}

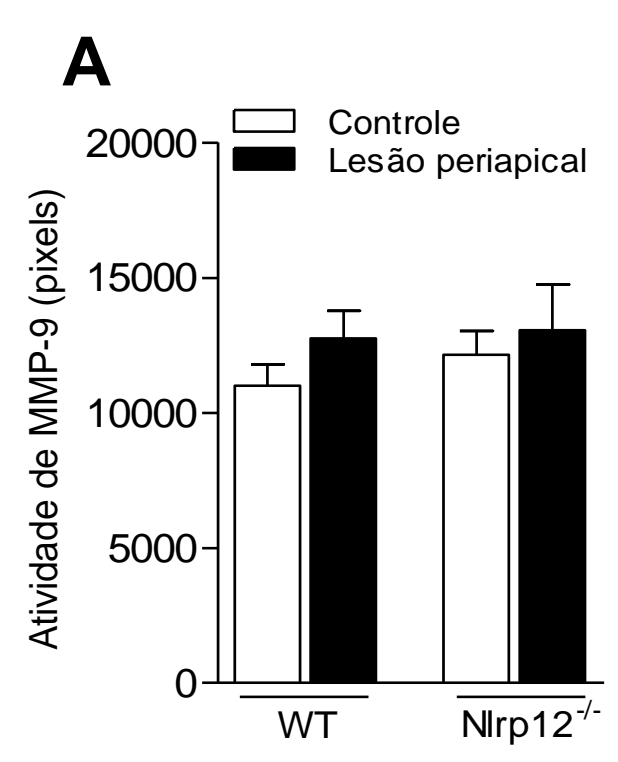

B

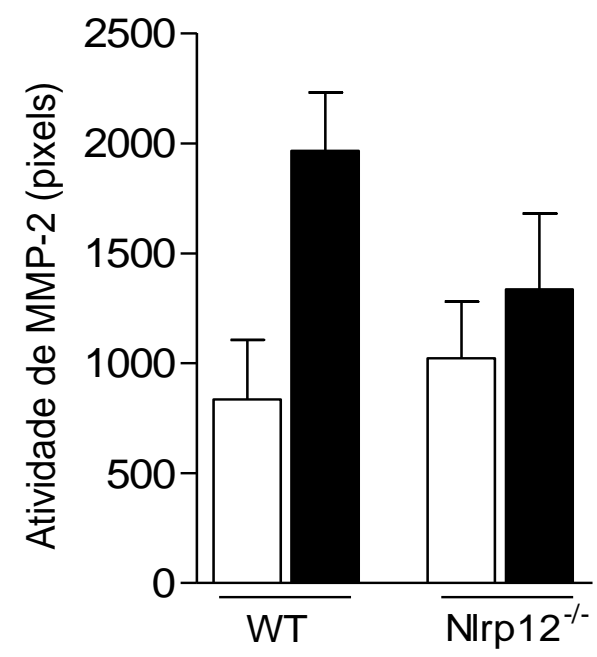



5. Discussão 



\section{DISCUSSÃO}

O presente estudo demonstra que a deficiência de NLRP12 potencializa a osteoclastogênese em células da linhagem mielóide sob o estímulo de M-CSF e RANKL após 4 dias de diferenciação. Esses dados confirmam dados prévios de Krauss et al. (2015) que demonstraram que a deficiência de NLRP12 aumentou não somente a formação de osteoclastos mas também a capacidade de reabsorção deste tipo celular.

Estudos prévios mostraram que NLRP12 é expresso em vários tipos celulares de tecidos humanos e murinos. Arthur et al. (2010) reportaram a expressão de Nlrp12 em células da medula óssea, baço, neutrófilos e em células dendríticas derivadas da medula óssea em camundongos. Zaki et al. (2011) compararam a expressão de Nlrp12 nas populações de células imunes em camundongos e detectaram que os neutrófilos apresentaram maiores níveis de expressão de NIrp12, seguidos de células $T$, células dendríticas e macrófagos. Similarmente, um estudo recente de Zamoshnikova et al. (2016) observou que NIrp12 foi altamente expresso em neutrófilos recrutados para o sítio inflamatório. Considerando que as células imuno-inflamatórias expressam o receptor Nlrp12, é sugestivo que este receptor possa exercer um papel na regulação da resposta inflamatória. E de fato, estudos in vivo tem demonstrado sua participação durante a resposta inflamatória frente a diversas infecções (Vladimer et al., 2012; Zaki et al., 2014; Silveira et al., 2017).

Dentre as patologias imuno-inflamatórias detectadas na odontologia, o modelo escolhido para a avaliação deste receptor foi o de periodontite apical induzida em camundongos. Os dados histológicos e moleculares do presente estudo mostraram que animais Nlrp12 $2^{-/}$apresentaram lesões maiores que o observado em animais WT ao 14 dias. E esse efeito não foi mais observado aos 21 dias de lesão. Portanto, os dados sugerem que NLRP12 exerce um papel protetor impedindo a progressão da lesão, especificamente, em estágios iniciais da doença.

Estudos histopatológicos, evidenciam que há duas fases distintas na doença periapical: a fase aguda, de 7 a 14 dias, seguida pela fase crônica, de 21 a 42 dias (Souza et al., 2014). Na fase aguda, a lesão é dominada por neutrófilos infiltrantes, e na fase crônica a presença prolongada de micro-organismos leva a uma mudança no 
padrão inflamatório da lesão, sendo os neutrófilos substituídos por macrófagos, linfócitos e células ricas em plasmas (Corotti et al., 2009). Sabe-se que Nlrp12 é altamente expresso em neutrófilos, os quais são as células predominantes nos estágios inicias do processo inflamatório. Desta forma, pode-se especular que a deficiência de NLRP12 nos neutrófilos comprometeu a resposta inicial e isso levou a um tamanho da lesão maior que nos animais WT apenas no período inicial da doença, aos 14 dias. Ainda, os neutrófilos aumentam a expressão de RANKL em sua membrana após o estímulo com LPS, demonstrando seu potencial direto na ativação da reabsorção óssea patológica através de interações com os osteoclastos (Chakravarti et al., 2009).

A deficiência de NLRP12 levou ao aumento da suscetibilidade a perda óssea em um outro modelo de perda óssea em calvária, induzida por RANKL. Sendo este um modelo não inflamatório, os autores sugerem que o papel protetor de NLRP12 sobre o tecido ósseo pode não ser exclusivamente por atenuar a resposta inflamatória local (Krauss et al., 2015).

Estudos in vitro com macrófagos humanos e murinos sugerem que o NLRP12 regula negativamente a produção de citocinas induzidas pela ativação do receptor Toll (TLR) (Lich et al., 2007, Williams et al., 2005; Zaki et al., 2011, Zaki et al., 2014). Também foi mostrado que a expressão de NLRP12 suprime a via alternativa de NF-kB (Zhong et al., 2013), que é um mediador central na produção de citocinas e quimiocinas. Além disso, a supressão da sinalização pró-inflamatória mediada por NLRP12 desempenha um papel central na atenuação da inflamação de cólon, tumorigênese (Zaki et al., 2011) e do desenvolvimento de encefalomielite em camundongos (Gharagozloo et al., 2015). Estes estudos estabelecem o NLRP12 como regulador de respostas inflamatórias em células imunes inatas. No entanto, o suposto papel de NLRP12 na regulação de células T durante a progressão da doença inflamatória não foi caracterizada (Lukens et al., 2015). A fim de avaliar a resposta imune gerada nos animais WT e Nlrp12 $\%$ frente à agressão nos tecidos periapicais, foi realizada a avaliação dos principais fatores de transcrição que regulam 0 desenvolvimento de respostas padrão Th1, Th2, Treg e Th17 em amostras de linfonodos cervicais. Estudos de Takahashi et al. (1999) e Tasman et al. (2000) mostraram que a resposta imune gerada em resposta ao processo 
inflamatório/infeccioso da lesão periapical é coordenada pelos linfonodos próximos à região.

Foi observado neste estudo que aos 14 dias de lesão houve uma menor expressão de T-bet em camundongos deficientes para NLRP12 em relação aos animais WT. Porém ao avaliar outros marcadores de células T, RORyt, GATA-3 e Foxp-3, vimos que a expressão gênica dos mesmos foram semelhantes entre os grupos WT e Nlrp12-/- nos períodos de 14 e 21 dias de lesão.

Há controvérsia na literatura sobre 0 efeito das células $T$ na osteoclastogênese, uma vez que RANKL é expresso em células $T$ ativas e portanto devem participar do processo de diferenciação dos osteoclastos (Kong et al., 1999, Horwood et al., 1999), todavia as células $T$ também secretam o IFN- $\gamma$, que contrabalanceia o efeito de RANKL, por isso os efeitos das células $T$ sobre a osteoclastogênese devem ser dependente do equilíbrio desses fatores (Sato et al., 2006). Sato et al., (2006) demonstraram em estudo in vitro que as células Th1 e Th2 possuem efeito inibitório dose-dependente na osteoclastogênese através da produção de grande quantidade de IFN-y e IL-4, respectivamente. Desta forma, é possível sugerir que no presente estudo, a menor expressão gênica de T-bet e consequentemente menor produção de IFN- $\gamma$, resultou no aumento da osteoclastogênese e maior lesão, observado aos 14 dias nos animais Nlrp12 ${ }^{-}$. Ainda, dados relatados por Sato et al., 2006 demonstraram que a célula Th17 estimula a osteoclastogênese, possivelmente via indução da expressão de RANKL nos osteoblastos pela citocina IL-17 (Kotake et al., 1999, Sato et al., 2006), entretanto não foi encontrado diferença de expressão desses marcadores entre os animais WT e Nlrp12-/ em nosso estudo.

Fukada et al., 2009 observaram que o desequilíbrio entre a imunidade e a atividade dos osteoclastos em lesões periapicais parece ser criticamente regulado por células Treg, porém Sato et al. (2006), mostraram que quando analisado os efeitos de células Treg $\mathrm{CD} 4{ }^{+} \mathrm{CD} 25^{+}$na osteoclastogênese tanto em cultura de osteoclastos quanto em co-cultura, estas não apresentaram nenhum efeito em ambas as situações, sugerindo que as células Treg não participam diretamente na regulação da reabsorção óssea. 
Dados do presente estudo sugerem que a maior perda óssea periapical nos camundongos Nlrp12-/- avaliada em imagens histológicas aos 14 dias de lesão, devese à maior capacidade reabsortiva dos osteoclastos verificada pela maior expressão gênica das enzimas Trap, Catepsina K e MMP-9 quando comparados com os animais WT. De fato, trabalhos in vitro e in vivo sugerem que dois tipos de proteases estão envolvidas na reabsorção óssea mediada pelos osteoclastos ao realizarem a degradação do colágeno do osso, a MMP-9 e a Catepsina K (Delaisse et al., 1987; 2003; Everts et al., 1992). Reforçando nossos dados, Gao et al. (2013) verificaram que, a Catepsina $\mathrm{K}$, quando silenciada, reduz significantemente a reabsorção e o desenvolvimento de lesões periapicais, demonstrando seu papel crucial no processo de reabsorção óssea. Aos 21 dias, essa diferença de expressão gênica tanto de Trap quanto de Catepsina K não foi observada entre os grupos WT e NIrp12\%- com lesão, assim como não houve diferença do tamanho da lesão entre os mesmos quando avaliados em cortes histológicos.

Ainda, Anan et al. (1993) observou que em dentes com necrose pulpar radicular há um aumento considerável de osteoclastos na região periapical do dente afetado quando comparado aos dentes sadios (controle). No ensaio enzimático de TRAP, os animais NIrp12\%- com lesão tiveram um maior número de células positivas para TRAP em relação ao seu controle, enquanto os animais WT não apresentaram diferença significativa entre seus grupos.

A destruição dos tecidos periapicais é acometida pela degradação dos componentes da matriz extracelular incluindo colágeno e proteoglicanos, e os responsáveis por esse mecanismo são as metaloproteinases da matriz (MMPs) (Buzoglu et al., 2009). As MMPs degradam a matriz extracelular tanto em condições fisiológicas quanto em circunstâncias patológicas como na periodontite (Xiong et al., 2010), estando associadas com altos níveis de inflamação e reabsorção óssea (Hill et al., 1994). Alguns estudos mostraram a participação das MMPs também na patogênese da inflamação pulpar e periapical (Wahlgren et al., 2002; Shin et al., 2002), sendo estas importantes no desenvolvimento de lesões periapicais inflamatórias (Corotti et al., 2009).

Vários membros da família MMP, incluindo MMP-1, -2, -3, -8, -9 e -13 estão envolvidos na patogênese da doença periapical (Corotti et al., 2009; Paula-Silva et 
al., 2010; Matsui et al., 2011). A MMP-1 tem sido implicada como uma enzima-chave na início da reabsorção óssea (Sasaki et al., 2007), enquanto MMP-2 e -MMP-9 são envolvidas na degradação da matriz extracelular, principalmente nos estágios ativos do desenvolvimento da lesão periapical (Corotti et al., 2009). Foi reportado um aumento dos níveis de MMP-2 e MMP-9 em periodontite apical crônica (Shin et al., 2002) e no fluido crevicular gengival de dentes com lesões periapicais (Belmar et al., 2008). Além disso a MMP-9 é essencial para iniciar o processo de reabsorção óssea, pois este remove a camada de colágeno da superfície óssea antes da desmineralização dar início (Delaissé et al., 2000). Em contrapartida, Tjäderhane et al. (2007) observaram que camundongos deficientes para MMP-9 tiveram um aumento da taxa de necrose pulpar seguido de uma maior resposta inflamatória, além de uma maior lesão periapical, sugerindo um papel anti-inflamatório da MMP-9. Esses autores explicam que esses resultados podem ser parcialmente explicados pela compensação de outros membros da família MMP ou outras proteinases, porém não pode ser excluída a hipótese de que pode haver outras vias que induzem a destruição óssea.

Semelhante ao trabalho de Souza et al. (2014), foi encontrado em nosso estudo uma alta expressão de MMP-9 aos 14 dias nos grupos com lesão, ressaltando que os animais NIrp12/- tiveram uma expressão ainda maior de MMP-9 em relação aos animais WT. Citocinas como a IL-1 e a IL-6, produzidas pelos neutrófilos, também podem induzir a produção e ativação das MMPs durante a fase aguda da lesão (Marton IJ e Kiss C, 2000). Sendo assim, avaliamos a atividade enzimática de MMP-9 e MMP-2 tanto em 14 quanto 21 dias de lesão. Aos 14 dias, foi observado uma maior atividade gelatinolítica de ambas enzimas MMP-9 e MMP-2 nas amostras do grupo NIrp12/- com lesão em relação ao seu controle. Isso sugere que estas enzimas poderiam estar atuando na degradação da matriz extracelular apical favorecendo uma expansão da lesão, provavelmente em conjunto com outras enzimas como o Trap e a Catepsina K. Nesta fase da doença, os animais WT com lesão tiveram uma maior expressão de MMP-9 quando comparados aos seus controles seguido de um aumento da atividade de MMP-9, entretanto esse aumento não foi significativo em ambas análises. E ao avaliar a atividade de MMP-2, o grupo controle e com lesão dos animais WT apresentaram um aumento semelhante entre 
eles. Dado isso, o papel das MMPs no processo inflamatório/infeccioso da lesão periapical pode ser complexo e multifatorial. Ainda aos 21 dias de lesão, os grupos controles e com lesão tanto de animais WT e Nlrp12\% se igualam na atividade de MMP-9, correlacionando com as análises histológicas neste período. E ao avaliar a atividade de MMP-2, verificamos uma maior atividade no grupo WT e Nlrp12-- com lesão em relação aos seus respectivos controles, embora um aumento não significativo, ademais, foi observado uma diminuição da atividade de MMP-2 em todos grupos. Esses resultados corroboram com um estudo anterior de Corotti et al., 2009 que relata uma maior expressão dessas MMPs na fase de desenvolvimento ativo de lesões periapicais induzidas em ratos e diminuição da expressão durante a fase crônica, indicando uma participação das MMP-2 e MMP-9 na fase inicial do desenvolvimento das lesões.

Ao longo deste estudo, foi observado que o receptor NLRP12 teve maior participação no período inicial do desenvolvimento da lesão periapical, uma vez que aos 14 dias de lesão os animais deficientes para NLRP12 desenvolveu uma lesão periapical maior, confirmados por um aumento de expressão dos marcadores de osteoclastos comparados aos animais WT. Além disso, Nlrp12\% com lesão apresentou maior quantidade de osteoclastos no local da lesão, seguidos de maior atividade gelatinolítica destes em relação a seus níveis basais. Nossos dados sugerem ainda que aos 21 dias, este receptor não continua atuando de modo protetor sobre o tecido ósseo durante a progressão da doença. 
6. Conclusão 



\section{CONCLUSÃO}

Até o momento não existem dados na literatura que relacionem o receptor NLRP12 com o desenvolvimento das lesões periapicais e muito pouco se sabe sobre o seu papel na modulação da osteoclastogênese e atividade dos osteoclastos. Ainda há muita controvérsia entre a relação de NLRP12 na regulação de respostas imunoinflamatórias frente a diversos tipos de infecção. Ao nosso ver, este é o primeiro estudo avaliando o receptor NLRP12 durante o progressão da lesão periapical induzida, e como demonstrado no modelo in vivo, NLRP12 detém a expansão da lesão periapical nos estágios iniciais da doença pela inibição do processo de reabsorção óssea. 

Referências 



\section{REFERÊNCIAS}

Akira S, Uematsu S, Takeuchi O. Pathogen recognition and innate immunity. Cell, vol. 124, no. 4, pp. 783-801, 2006.

Allen IC, Lich JD, Arthur JC, Jania CM, Roberts RA, Callaway JB, Tilley SL, Ting JP. Characterization of NLRP12 during the Development of Allergic Airway Disease in Mice. PLoS One. 2012; 7(1): e30612.

Allen IC, Moore $C B$, Schneider $M$, Lei $Y$, Davis BK, Scull MA, Gris D, Roney KE, Zimmermann AG, Bowzard JB, Ranjan P, Monroe KM, Pickles RJ, Sambhara $\mathrm{S}$, Ting JP. NLRX1 Protein Attenuates Inflammatory Responses to Infection by Interfering with the RIG-I-MAVS and TRAF6-NF-kB Signaling Pathways. Immunity. 2011; 34(6): 854-865.

Allen IC, Wilson JE, Schneider M, Lich JD, Authur JC, et al. NLRP12 Functions as a Negative Regulator of Noncanonical NF-kB Signaling and Tumorigenesis during Colitis Associated Cancer. Immunity. 2012; 36(5): 742-54.

Arthur JC, Lich JD, Ye Z, Allen IC, Gris D, Wilson JE, Schneider M, Roney $\mathrm{KE}$, O'Connor BP, Moore CB, Morrison A, Sutterwala FS, Bertin J, Koller BH, Liu $Z$, Ting JP. Cutting edge: NLRP12 controls dendritic and myeloid cell migration to affect contact hypersensitivity. J Immuno/ 2010; 185: 4515-4519.

Aubin JE. Regulation of osteoblast formation and function. Reviews in endocrine \& metabolic disorders. 2001;2(1):81-94.

Barton, G. M. A calculated response: control of inflammation by the innate immune system. J. Clin. Invest. 2008. Feb;118(2):413-20.

Belmar MJ, Pabst C, Martínez B, Hernández M. Gelatinolytic activity in gingival crevicular fluid from teeth with periapical lesions. Oral Surg Oral Med Oral Pathol Oral Radiol Endod 2008; 105:801-6.

Boyle WJ, Simonet WS \& Lacey DL. Osteoclast differentiation and activation. Nature 423. 2003;15: 337-342.

Buzoglu HD, Unal $\quad H$, Ulger $\quad$ C, Mert $\quad S$, Kücükyildirim $\quad$ S, Er $\quad N$. The zymographic evaluation of gelatinase (MMP-2 and

9) levels in acute and chronic periapical abscesses. Oral Surg Oral Med Oral Pathol Oral Radiol Endod. 2009 Nov; 108(5):e121-6.

Carneiro LAM and Travessos LH. The interplay between NLRs and autophagy in immunity and inflammation. Front. Immunol. 2013; 4:361.

Chakravarti A, Raquil MA, Tessier P, Poubelle PE. Surface RANKL of Toll-like receptor 4-stimulated human neutrophils activates osteoclastic bone resorption. Blood. 2009 Aug 20;114(8):1633-44. 
Conti BJ, Davis BK, Zhang J, O'connor W Jr, Williams KL, Ting JP. CATERPILLER 16.2 (CLR16.2), a novel NBD/LRR family member that negatively regulates $T$ cell function. $\mathrm{J}$ Biol Chem 2005; 280(18):18375-8.

Corotti MV, Zambuzzi WF, Paiva KB, Menezes R, Pinto LC, Lara VS, Granjeiro JM. Immunolocalization of matrix metalloproteinases-2 and -9 during apical periodontitis development. Arch Oral Biol. 2009; 54(8):764-71.

Cui J, Zhu L, Xia X, Wang HY, Legras X, Hong J, Ji J, Shen P, Zheng S, Chen ZJ, Wang RF. NLRC5 negatively regulates the NF kappaB and type I interferon signaling pathways. Cell. 2010; 141: 483-496.

Da Silva RAB, Ferreira PDF, De Rossi A, Nelson-Filho P, Silva LAB. Toll-like Receptor 2 Knockout Mice Showed Increased Periapical Lesion Size and Osteoclast Number. Journal of Endodontics. 2012; 38(6):803-13.

Delaisse JM, Andersen TL, Engsig MT, Henriksen K, Troen T, Blavier L. Matrix metalloproteinases (MMP) and cathepsin K contribute differently to osteoclastic activities. Microsc Res Tech. 2003; 61(6):504-13.

Delaisse JM, Boyde A, Maconnachie E, Ali NN, Sear CH, Eeckhout Y, et al. The effects of inhibitors of cysteine-proteinases and collagenase on the resorptive activity of isolated osteoclasts. Bone. 1987; 8(5):305-13.

Delaissé JM, Everts V, del Carmen Ovejero M, Ferreras M, Lund L, Vu TH, Werb Z, Winding B, Lochter A, Karsdal MA, Troen T, Kirkegaard T, Lenhard T, Heegaard AM, Neff L, Baron R, Foged NT. Proteinases in bone resorption: obvious and less obvious roles. Clin Chim Acta. 2000 Feb 15; 291(2):22334.

De Rossi A, Rocha LB, Rossi MA. Interferon-gamma, Interleukin-10, Intercellular Adhesion Molecule-1, and Chemokine Receptor 5, but not Interleukin-4, Attenuate the Development of Periapical Lesions. Journal of Endodontics. 2008; 34(1):31-8.

Del Fattore A, Teti A. The tight relationship between osteoclasts and the immune system. Inflamm Allergy Drug Targets. 2012; 11(3):181-7.

Everts V, Delaisse JM, Korper W, Niehof A, Vaes G, Beertsen W. Degradation of collagen in the bone-resorbing compartment underlying the osteoclast involves both cysteine-proteinases and matrix metalloproteinases. J Cell Physiol. 1992; 150(2):22131.

Feng W, Xia W, Ye Q, Wu W. Osteoclastogenesis and osteoimmunology. Front Biosci (Landmark Ed). 2014; 1;19:758-67.

Fukada SY, Silva TA, Garlet GP, Rosa AL, da Silva JS, Cunha FQ. Factors involved in the $T$ helper type 1 and type 2 cell commitment and osteoclast regulation in inflammatory apical diseases. Oral Microbiol Immunol. 2009; 24(1):25-31. 
Gao B, Chen W, Hao L, Zhu G, Feng S, Ci H, Zhou X, Stashenko P, Li YP. Inhibiting periapical lesions through AAV-RNAi silencing of cathpesin K. J Dent Res. 2013 Feb;92(2):180-6.

Gharagozloo M, Mahvelati TM, Imbeault E, Gris $P$, Zerif E, Bobbala D, Ilangumaran S, Amrani A, Gris D. The nod-like receptor, NIrp12, plays an anti-inflammatory role in experimental autoimmune encephalomyelitis. J Neuroinflammation. 2015 Oct 31; 12:198.

Gowen M, Wood DD, Ihrie EJ, McGuire MK, Russell RG. An interleukin 1 like factor stimulates bone resorption in vitro. Nature. 1983 Nov 24-30; 306(5941):378-80.

Gravizoda D, Dzopalic T, Bozic B, Tatomirovic Z, Brkic Z, Colic M. Production of proinflammatory and immunoregulatory cytokines by inflammator y cells from periapical lesionsin culture. J. Oral Pathol Med. 2009; 38(7):605-11.

Guerrini MM, Takayanagi H. The immune system, bone and RANKL. Archives of Biochemistry and Biophysics. 2014;561; 118-123.

Henriques LC, de Brito LC, Tavares WL, Vieira LQ, Ribeiro Sobrinho AP. Cytokine analysis in lesions refractory to endodontic treatment. J Endod 2011; 37:1659-62.

Horwood, N.J., V. Kartsogiannis, J.M. Quinn, E. Romas, T.J. Martin, and M.T. Gillespie. Activated T lymphocytes support osteoclast formation in vitro. Biochem. Biophys. Res. 1999; 265:144-150.

Jang JH, Shin HW, Lee JM, Lee HW, Kim EC, Park SH. Na Overview of Pathogen Recognition Receptors for Innate Immunity in Dental Pulp. Mediators Inflamm. 2015; 2015:794143.

Jankovic D, Liu Z, Gause WC. Th1- and Th2-cell commitment during infectious disease: asymmetry in divergent pathways. Trends Immunol. 2001; 22(8):450-7.

Kawai T and Akira S. The roles of TLRs, RLRs and NLRs in pathogen recognition. International Immunology, vol. 21, no. 4, pp. 317-337, 2009.

Khosla S. Minireview: The OPG/RANKL/RANK System. Endocrinology. 2001; 142(12):5050-5.

Kim YK, Shin JS, Nahm MH. NOD-Like Receptors in Infection, Immunity and, Diseases. Yonsei Med J. 2016; 57(1):5-14.

Kong YY, Feige U, Sarosi I, Bolon B, Tafuri A, Morony S, Capparelli C, Li J, Elliott R, McCabe S, Wong T, Campagnuolo G, Moran E, Bogoch ER, Van G, Nguyen LT, Ohashi PS, Lacey DL, Fish E, Boyle WJ, Penninger JM. Activated T cells regulate bone loss and joint destruction in adjuvant arthritis through osteoprotegerin ligand. Nature. 1999; 402:304-309.

Kotake S, Udagawa N, Takahashi N, Matsuzaki K, Itoh K, Ishiyama S, Saito S, Inoue K, Kamatani N, Gillespie MT, Martin TJ, Suda T. IL-17 in synovial fluids from patients 
with rheumatoid arthritis is a potent stimulator of osteoclastogenesis. J Clin Invest. 1999 May;103(9):1345-52.

Krauss JL, Zeng R, Hickman-Brecks CL, Wilson JE, Ting JP, Novack DV. NLRP12 provides a critical checkpoint for osteoclast differention. Proc Natl Acad Sci U S A. 2015; 18;112(33):10455-60.

Kufer TA, Sansonetti PJ. NLR functions beyond pathogen recognition. Nat Immunol. 2011 Feb;12(2):121-8.

Lacey DL, Timms E, Tan HL, Kelley MJ, Dunstan CR, Burgess T, Elliott R, Colombero A, Elliott G, Scully S, Hsu H, Sullivan J, Hawkins N, Davy E, Capparelli C, Eli A, Qian YX, Kaufman S, Sarosi I, Shalhoub V, Senaldi G, Guo J, Delaney J, Boyle WJ.. Osteoprotegerin ligand is a cytokine that regulates osteoclast differentiation and activation. Cell. 1998; 93:165-76.

Lampiasi N, Russo R, Zito $F$. The alternative faces of macrophage generate osteoclasts. Biomed Res Int. 2016; 9089610.

Leonardo MR, Rossi MA, Silva LA, Ito IY, Bonifácio KC. EM evaluation of bacterial biofilm and microorganisms on the apical external root surfasse of human teeth. $J$ Endod. 2002 Dec; 28(12):815-8.

Lich JD, Williams KL, Moore CB, Arthur JC, Davis BK, et al. Monarch- 1 suppresses non-canonical NF-kappaB activation and p52 dependent chemokine expression in monocytes. J Immunol. 2007; 178:1256-1260.

Livak KJ, Schmittgen TD. Analysis of relative gene expression data using real-time quantitative PCR and the 2(-Delta Delta C(T)) Method. Methods. 2001;25(4):402-8.

Lukens JR, Gurung P, Shaw PJ, Barr MJ, Zaki MH, Brown SA, Vogel P, Chi $\mathrm{H}$, Kanneganti TD. The NLRP12 sensor negatively regulates autoinflammatory disease by modulating Interleukin-4 production in T cells. Immunity. 2015 Apr 21; 42(4):654-64.

Manolagas SC. Birth and death of bone cells: basic regulatory mechanisms and implications for the pathogenesis and treatment of osteoporosis. Endocrine reviews. 2000;21: 115-137.

Marçal JR, Samuel RO, Fernandes D, de Araujo MS, Napimoga MH, Pereira SA, Clemente-Napimoga JT, Alves PM, Mattar R, Rodrigues V Jr, Rodrigues DB. Thelper cell type 17/regulatory T-cell immunoregulatory balance in human radicular cysts and periapical granulomas. $J$ Endod. 2010; 36:995-9.

Márton IJ, Kiss C. Protective and destructive imune reactions in apical periodontitis. Oral Microbiol Immunol. 2000; 15(3):139-50.

Matsui H, Yamasaki M, Nakata K, Amano K, Nakamura H. Expression of MMP-8 and MMP-13 in the development of periradicular lesions. Int Endod J. 2011; 44(8):73945. 
Metzger Z. Macrophages in periapical lesions. Endod Dent Traumatol. 2000 Feb;16(1):1-8

Nair PN. Pathogenesis of apical periodontitis and causes of endodontic failures. Crit Rev Oral Biol Med. 2004; 15(6):348-81.

Nakagawa N, Kinosaki M, Yamaguchi K, Shima N, Yasuda H, Yano K, Morinaga T, Higashio K. RANK is the essential signaling receptor for osteoclast differentiation factor in osteoclastogenesis. Biochem Biophys Res Commun. 1998; 18;253(2):395400.

Nakashima T, Hayashi M, Takayanagi H. New insights into osteoclastogenic signaling mechanisms. Trends Endocrinol Metab. 2012; 23(11):582-90.

Novack DV, Teitelbaum SL. The osteoclast: friend or foe? Annual review of pathology. 2008; 3: 457-484.

Paula-Silva FW, da Silva LA, Kapila YL. Matrix metalloproteinase expression in teeth with apical periodontitis is differentially modulated by the modality of root canal treatment. J Endod. 2010; 36(2):231-7.

Paula-Silva FW, Petean IB, da Silva LA, Faccioli LH. Dual role of 5-Lipoxygenase in osteoclastogenesis in bacterial-induced apical periodontitis. J Endod. 2016; 42(3):447-54.

Rho J, Takami M, Choi Y. Osteoimmunology: Interactions of the immune and skeletal systems. Mol Cells. 2004; 29;17(1):1-9.

Ribeiro-Sobrinho AP, Rabelo FL, Figueiredo CB, Alvarez-Leite JI, Nicoli JR, Uzeda $M$, Vieira LQ. Bacteria recovered from dental pulp induce apoptosis of lymph node cells. J Med Microbiol. 2005; 54(Pt 4):413-6.

Rocha CT, Rossi MA, Leonardo MR, Rocha LB, Nelson-Filho P, Silva LA. Biofilm on the apical region of roots in primary teeth with vital and necrotic pulps with or without radiographically evidente apical pathosis. Int Endod J. 2008 Aug;41(8):664-9.

Rocha DAP, Pereira KMA, Gordón-Núñez MA, Carvalho RA, Galvão HC, Costa ALL. Formación de los granulomas y quistes radiculares: uma revisión de los aspectos inmunopatológicos. Ver ADM 2007; 64(3):91-6.

Sasaki K, Takagi M, Konttinen YT, Sasaki A, Tamaki Y, Ogino T, et al. Upregulation of matrix metalloproteinase (MMP)-1 and its activator MMP-3 of human osteoblast by uniaxial cyclic stimulation. J Biomed Mater Res B: Appl Biomater. 2007; 80(2):491-8.

Sato K, Suematsu A, Okamoto K, Yamaguchi A, Morishita Y, Kadono Y, Tanaka S, Kodama T, Akira S, Iwakura Y, Cua DJ, Takayanagi H. Th17 functions as an osteoclastogenic helper $\mathrm{T}$ cell subset that links $\mathrm{T}$ cell activation and bone destruction. J Exp Med. 2006 Nov 27;203(12):2673-82. 
Schneider M, Zimmermann AG, Roberts RA, Zhang L, Swanson KV, Wen H, Davis BK, Allen IC, Holl EK, Ye Z, Rahman AH, Conti BJ, Eitas TK, Koller BH, Ting JP. NLRC3 Attenuates TLR Signaling via Modification of TRAF6 and NFkB. Nature Immunology. 2012;13(9): 823-31.

Shin SJ, Lee JI, Baek SH, Lim SS. Tissue levels of matrix metalloproteinases in pulps and periapical lesions. J Endod. 2002 Apr;28(4):313-5.

Silveira TN, Gomes MT, Oliveira LS, Campos PC, Machado GG, Oliveira SC. NLRP12 negatively regulates proinflammatory cytokine production and host defense against Brucella abortus. Eur J Immunol. 2017 Jan;47(1):51-59.

Sims NA, Gooi JH. Bone remodeling: Multiple cellular interactions required for coupling of bone formation and resorption. Semin Cell Dev Biol. 2008; 19(5):444-51.

Sousa NG, Cardoso CR, Silva JS, Kuga MC, Tanomaru-Filho M, Faria G. Association of matrix metalloproteinase inducer (EMMPRIN) with the expression of matrix metalloproteinases-1, -2 and -9 during periapical lesion development. Arch Oral Biol. 2014 Sep;59(9):944-53.

Soysa NS, Alles N, Takahashi M, Aoki K, Ohya K. Defective nuclear factor-kB inducing kinase in aly/aly mice prevents bone resorption induced by local injection of lipopolysaccharide. J Periodontal Res. 2011; 46(2): 280-4.

Stashenko P, Wang CY, Tani-Ishii N, Yu SM. Pathogenesis of induced rat periapical lesions. Oral Surg Oral Med Oral Pathol. 1994 Oct;78(4):494-502.

Takahashi K, MacDonald D, Murayama Y, Kinana D. Cell synthesis, proliferation and apoptosis in human dental periapical lesions analysed by in situ hybridization and immunohistochemistry. Oral Dis. 1999 Oct;5(4):313-20.

Takayanagi H. New developments in osteoimmunology. Nat Rev Rheumatol. 2012; 8(11):684-9.

Tanaka H, Tanabe N, Kawato T, Nakai K, Kariya T, Matsumoto S, Zhao N, Motohashi $M$, Maeno $M$. Nicotine affects bone resorption and suppresses the expression of cathepsin K, MMP-9 and vacuolar-type $\mathrm{H}(+)$-ATPase $\mathrm{d} 2$ and actin organization in osteoclasts. PLoS One. 2013; 8(3):e59402.

Tasman F, Er N, Ataç A, Dagderiven A, Kendir B. CD45/isotypes expression in immune cells of human periapical lesions. J Endod. 2000 Mar;26(3):166-8.

Tjäderhane L, Hotakainen T, Kinnunen S, Ahonen M, Salo T. The effect of chemical inhibition of matrix metalloproteinases on the size of experimentally induced apical periodontitis. Int Endod J. 2007; 40:282-9.

Teronen O, Luoto H, Sorsa T, Tjäderhane L. Matrix metalloproteinase-8 (MMP-8) in pulpal and periapical inflammation and periapical root-canal exudates. Int Endod J. 2002 Nov;35(11):897-904. 
Tuncer S, Fiorillo MT, Sorrentino R. The multifaceted nature of NLRP12. J Leukoc Biol. 2014 Dec;96(6):991-1000.

Williams KL, Lich JD, Duncan JA, Reed W, Rallabhandi P, et al. The CATERPILLER protein monarch-1 is an antagonist of toll-like receptor-, tumor necrosis factor alphaand Mycobacterium tuberculosis-induced pro-inflammatory signals. $\mathrm{J} \mathrm{Biol} \mathrm{Chem}$. 2005; 280: 39914-39924.

Williams KL, Taxman DJ, Linhoff MW, Reed W, Ting JP. Cutting edge: Monarch-1: a pyrin/nucleotide-binding domain/leucine-rich repeat protein that controls classical and nonclassical MHC class I genes. J Immuno/ 2003; 170: 5354- 5358.

Wilson SR, Peters C, Saftig P, Brömme D. Cathepsin K activity-dependent regulation of osteoclast actin ring formation and bone resorption. J Biol Chem. 2009 Jan 23;284(4):2584-92.

Yavropoulou MP, Yovos JG. Osteoclastogenesis-current knowledge and future perspectives. J Musculoskelet Neuronal Interact. 2008; 8(3):204-16.

Yu SM, Stashenko P. Identification of inflammatory cells in developing rat periapical lesions. J Endod 13. 1987, pp. 535-540.

Zamoshnikova A, Groß CJ, Schuster S, Chen KW, Wilson A, Tacchini-Cottier F, Schroder K. NLRP12 is a neutrophil-specific, negative regulator of in vitro cell migration but does not modulate LPS- or infection-induced NF-kB or ERK signilling. Immunobiology. 2016 Feb; 221(2):341-6.

Zaki MH, Man SM, Vogel P, Lamkanfi M, Kanneganti TD. Salmonella exploits NLRP12dependent innate immune signaling to suppress host defenses during infection. Proc Natl Acad Sci U S A. 2014 Jan 7; 111(1):385-90.

Zaki MH, Vogel P, Malireddi RK, Body-Malapel M, Anand PK, et al. The NOD like receptor NLRP12 attenuates colon inflammation and tumorigenesis. Cancer Cell. 2011; 20(5): 649-60.

Zehnder M, Belibasakis GN. On the dynamics of root canal infections-what we undestand and what we don't. Virulence. 2015; 6(3):216-22.

Zhong Y, Kinio A, Saleh M. Functions of NOD-like receptors in human diseases. Front Immunol. 2013; 16;4:333. 
Anexo 



\section{UNIVERSIDADE DE SÃO PAULO \\ Faculdade de Ciências Farmacêuticas de Ribeirão Preto \\ COMISSAO DE ÉTICA NO USO DE ANIMAIS}

\section{A U T O R I Z A Ç Ã O}

Certificamos que a proposta intitulada "Papel do NLRP12 na progressão da lesão periapical", registrada sob $n^{\circ} 16.5 .162 .60 .9$, sob a responsabilidade de Thaise Mayumi Taira e Sandra Yasuyo Fukada Alves, que envolve a manutençăo e utilizaçăo de animais pertencentes ao filo Chordata, subfilo Vertebrata (exceto o homem) para fins de pesquisa cientifica encontrase de acordo com os preceitos da Lei $n^{\circ} 11.794$, de 8 de outubro de 2008 , do Decreto ${ }^{\circ} 6.899$, de 15 de julho de 2009, e com as normas editadas pelo Conselho Nacional de Controle da Experimentaçāo Animal (CONCEA), foi aprovada pela Comissão de Ética no Uso de Animais da Faculdade de Ciências Farmacêuticas de Ribeirão Preto (CEUA FCFRP) na reunião de 28/09/2016.

\begin{tabular}{|c|c|c|}
\hline Finalidade & \multicolumn{2}{|c|}{ ( ) Ensino ( $x$ ) Pesquisa Cientifica } \\
\hline Vigência da Autorização & \multicolumn{2}{|c|}{$30 / 09 / 2016$ a $30 / 06 / 2017$} \\
\hline Especie/Linhagem/Raça & $\begin{array}{l}\text { Camundongo isogênico C57 } \\
\text { BL } 6\end{array}$ & $\begin{array}{l}\text { Camundongo knouckout } \\
\text { C57BL6 }\end{array}$ \\
\hline $\mathrm{N}^{\circ}$ de animais & 60 & 60 \\
\hline Peso/ldade & $18-20 \mathrm{~g} / 6$ a 8 semanas & $18-20 \mathrm{~g} / 6$ a 8 semanas \\
\hline Sexo & Fêmea & Fermea \\
\hline Origem & Biotério Imunologia FMRP & Biotério Central da PUSP RP \\
\hline
\end{tabular}

Lembramos da obrigatoriedade de apresentação do relatório de atividades, em modelo da CEUA, para emissão do certificado, como disposto nas Resoluçōes Normativas do CONCEA.

Ribeirăo Preto, 30 de setembro de 2016.

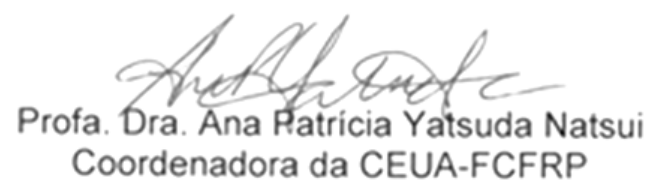

Avenida do Cale SN - Monte Alogre - CEP 14040-903 - Ribeir30 Preto - SP

Comissto de Étca no Uso de Animas - ceua Gtctop usp be

Fone: (16) 3315-4213:4216 - Fax (16) $33152-4892$ 